\title{
First in situ pXRF analyses of rock paintings in Erongo, Namibia: results, current limits, and prospects
}

\author{
Guilhem Mauran $^{1}$ \& Matthieu Lebon ${ }^{1}$ \& Florent Détroit ${ }^{1}$ \& Benoît Caron ${ }^{2}$ \& Alma Nankela ${ }^{3}$ \& David Pleurdeau ${ }^{1}$ \\ \& Jean-Jacques Bahain ${ }^{1}$
}

UMR 7194 Histoire Naturelle de l'Homme Préhistorique (HNHP), MNHN- CNRS-UPVD, Alliance Sorbonne Université, Muséum National d'Histoire Naturelle, Musée de l'Homme, 17 Place du Trocadéro, 75116 Paris, France

2 UMR 7193 Institut des Sciences de la Terre de Paris (ISTeP), Sorbonne Université-CNRS, Alliance Sorbonne Université, 4 Pl. Jussieu, 75005 Paris, France

3 Department of Archaeology and Heritage Research, National Heritage Council of Namibia, 52 Robert Mugabe Avenue, Ausspannplatz, Windhoek, Namibia

Corresponding author: Guilhem Mauran: guilhem.mauran1@edu.mnhn.fr

\section{To cite this article}

Guilhem Mauran, Matthieu Lebon, Florent Detroit, Benoît Caron, Alma Nankela, et al.. First in situ pXRF analyses of rock paintings in Erongo, Namibia: results, current limits, and prospects. Archaeological and Anthropological Sciences, Springer, 2019, 11, pp.4123-4145. 〈DOI: 10.1007/s12520-019-00787-7〉

\begin{abstract}
Namibia is one of the southern African countries hosting the richest rock art heritage, with thousands of rock paintings. Although numerous studies investigated their distribution, style, and possible meaning, few are known about the materials used to perform these paintings. Our in situ study aimed at identifying the diversity of pigments and alterations of some rock paintings in the northwestern part of the Erongo (Namibia). It relies on extensive pXRF analyses of 35 figures from eight rock art sites of the area. Despite common limits of in situ pXRF analyses, the extensive number of figures analyzed and the original data treatment that we performed pioneered the first scientific analyses of the pigments from rock painting sites in the Erongo Mountains. Furthermore, the study also confirmed the presence of iron oxide pigments on a portion of wall exposed during the excavations carried out at the archeological site of Leopard Cave and of possibly datable alterations over several paintings, paving the way to future chronological analyses of past tradition of rock paintings in Central Namibia.
\end{abstract}

\section{Keywords}

pXRF 'In situ 'Rock art 'Pigments 'Namibia 'Erongo

\section{Introduction}

Analyzing rock art pigments and their provenience aid our understanding of the way of life of past artists. Rock painting figures being extremely fragile, it is crucial that scientific studies involve in situ non-destructive analyses to investigate the nature of the pictorial layer and their state of conservation.

Among the portable techniques, researchers largely developed the use of portable X-ray fluorescence (pXRF) for archeological materials. This non-invasive analytical technique is fast, easy to use, cost-effective, involves multi-elemental screening, and requires minimal to no preparation of the samples, explaining the extensive rise of pXRF applications in archeological context (Shackley 2011). It allowed the investigation of the composition (e.g., Charalambous et al. 2014; Fontana et al. 2014; Maddhusudan Mehta et al. 2017), provenance (e.g., Goren et al. 2011), and authenticity (e.g., Ferreti et al. 2013) of archeological materials.

As for rock paintings themselves, thanks to the elemental information gathered, it gives information on chronology (Huntley et al. 2018; Wesley et al. 2014) or provenance of raw materials used to perform some paintings (Bedford et al. 2014; Huntley et al. 2013; Wallis et al. 2017). Although in situ pXRF analyses remained scarce in Africa (Steyn 2014), they have been carried out intensively in America (Appoloni et al. 2009; Bedford et al. 2014, 2018; Koenig et al. 2014; Loendorf and Loendorf 2013; Newman and Loendorf 2005; Sepúlveda et al. 2015: Velliky and Reimer/Yumks 2013), Australia (Huntley 2012, 2015; Huntley et al. 2013, 2016, 2018; Huntley and Galamban 2016; Wallis et al. 2017; Wesley et al. 2014), and Europe (Beck et al. 2012, 2014; Gay et al. 2015, 2016; López-Montalvo et al. 2014; Nuevo et al. 2012; Olivares et al. 2013; Roldán et al. 2010; Sanoit et al. 2005; Silva et al. 2017). 
The extensive rise of pXRF applications resulted in the implementation of various procedures, which led few studies to question the methodology to conduct significant and archeological successful pXRF analyses (Frahm and Doonan 2013). Other presented the limits of the technique such as the penetration depth of the X-rays. The spectra collected include information coming from the paint layer, the substrate, and their alterations (Gay et al. 2016; Huntley 2012; Huntley and Galamban 2016; Koenig et al. 2014; López-Montalvo et al. 2014; Roldán et al. 2010). They also pointed out other issues of pXRF in situ analyses such as the impossibility to provide absolute quantitative data, the complexity to conduct semi-quantitative analyses (Gay et al. 2016; Koenig et al. 2014), the necessity to take into consideration the heterogeneity of the substrate (Gay et al. 2016; Huntley 2012; Koenig et al. 2014), and the taphonomic phenomena affecting both the sub-strate and the pictorial layer (Huntley 2012, 2015). They all demonstrated the necessity to perform and interpret pXRF experiments with caution. As mentioned by Huntley and Galamban (2016), portable XRF analyses cannot replace lab-oratory analyses. They are preliminary steps assessing the nature and conservation state of the rock paintings.

To our knowledge, the current study presents the first in situ analyses of Namibian rock art, as well as the first field pXRF study carried out on paintings lying on granite. In essence, it pioneered scientific analyses of the pigments from rock painting sites in the northwestern part of Erongo.

Investigations focused on three different goals: the identification of the pigments used to perform the paintings on the heterogeneous granitic substrate, the identification of the alterations that cover some of the paintings, and to identify chemical element markers of pigment provenience.

\section{Archeological context of the Erongo rock art}

Central Namibia is famous for its thousands of ancient rock paintings, mostly found inside the granitic massifs of the Brandberg, the Spitzkopje, and the Erongo (Breuil 1955, 1975; Breuil et al. 1960; Nankela 2017; Pager et al. 1989; Scherz 1970). Breuil et al. (1960) first recorded rock art sites of the Erongo region, inventing most of the sites considered in the present study. Scherz (1970) extended his work and documented further the sites in Omandumba. More recently, Nankela (2017) conducted a systematic study of the sites and focused on their distribution, density, possible functionality, and their connection to their environment. All three provided an extensive overview of the styles and distribution of the paintings in this region, providing crucial data to perform the present study.

So far, a sole study dealt with the identification of the pigments used in Namibian rock art. It mainly focused on the search for carbonaceous materials to perform ${ }^{14} \mathrm{C}$ dating of the paintings (Conard et al. 1988). It makes Namibian rock art chronology to rest only on style analyses and comparison with South African rock art.

Styles and techniques analyses attribute these artworks to the hunter-gatherer San populations who inhabited the region for millennia. They are mainly characterized by anthropomorphic and zoomorphic figures depicting various scenes including hunting, landscape features, social gatherings, ritual practices, etc. (Nankela 2017; Richter 1995, 2002; Richter and Vogelsang 2008; Scherz 1970). Studies of southern African rock art mostly consist of historical-ethnological notes (Bleek and Lloyd 1911; Rudner 1982, 1983), stylistic analyses (Dowson 1994; Nankela 2015; Richter 2002; Richter and Vogelsang 2008), and interpretation studies (Lenssen-Erz 1996, 1997; Lewis-Williams 1972, 1974, 1975, 1980, 1981; Vinnicombe 1972, 1976; Willcox 1978). Few recent studies, mostly focusing on rock art of South Africa and Lesotho, also include analyses of the pigments used (Bonneau 2016; Bonneau et al. 2012, 2017; Prinsloo et al. 2008; Steyn 2014; Tournié et al. 2011). Among them, only a few have been applied in situ on southern African paintings such as Raman spectroscopy (Prinsloo et al. 2008; Tournié et al. 2011) and Xray fluorescence (Steyn 2014).

In the northwestern part of the Erongo, rock paintings feature zoomorphic and anthropomorphic scenes, with time-to-time superimposition of motifs. Sites also host few geometric and unidentified figures (Breuil et al. 1960; Nankela 2017; Scherz 1970).

Colors used range from red (commonly) hues to black (occasionally), white (rarely), and yellow (hardly ever). The investigated rock paintings present most colors and themes identified by previous studies (Breuil et al. 1960; Nankela 2017; Scherz 1970). To our knowledge, previous works recorded only a few yellow paintings in the area (Breuil et al. 1960).

Within this region, two ornate archeological sites provided numerous coloring materials at the bottom of the paintings: Fackelträger and Leopard Cave (Wendt 1972; Richter 1991; Pleurdeau et al. 2012). At both sites, excavations unearthed coloring materials and tools bearing traces of pigments in levels dated from 3000 to 2000 Cal. BP (Wendt 1972; Richter 1991; Pleurdeau et al. 2012). 


\section{Materials and methods}

\section{Paintings and sites}

The investigation concentrated on 35 painted figures found at eight distinct sites all located in the northwestern part of the Erongo (Fig. 1). All of these paintings were recorded and de-scribed by Nankela (2017). The sites constitute a set of five shelters and three walls considered as representative of parietal rock art sites in the Omandumba and Anibib farms, and the Tubusis communal area, in the northwestern part of the Erongo Mountains. Table 1 lists the sites analyzed during the study, specifying the archeological data connected to them, some of their geomorphological characteristics (setting and nature of the bedrock), and the summary of the analyses carried out on each site.

The analyses focused on black, white, and red paintings as recorded by Nankela (2017). Due to the accessibility and state of preservation of the yellow representations mentioned by Breuil et al. (1960), their analyses could not be included to the present study.

The rock paintings considered in this study all lie on an un-evenly altered granitic substrate of the Erongo granite member (code member KgEGg - Schreiber et al. 2010), found in and around the area of the present study over $100 \mathrm{~km}^{2}$ (Blümel et al. 1979) and corresponding to the magmatic chamber of the Mesozoic Erongo volcano. The Erongo granite is a massive, coarsegrained, sub-solvus biotite granite. It is heterogeneous, ranging from grayish white to yellow with various abundance and facies of millimetric to pluri-centimetric schorl $\left(\mathrm{SiO}_{2}-\mathrm{NaFe}_{3} \mathrm{Al}_{6}\left(\mathrm{BO}_{3}\right)_{3}\left(\mathrm{Si}_{6} \mathrm{O}_{18}\right)(\mathrm{OH})_{4}\right)$ inclusions. Blümel et al. (1979) reported the average granite modal composition to be $36 \%$ quartz $\left(\mathrm{SiO}_{2}\right), 33 \%$ perthitic orthoclase (intergrowths of a $\mathrm{K}$-feldspar like $\left(\mathrm{KAlSi}_{3} \mathrm{O}\right)$ and a sodic alkali feldspar $\left.\left(\mathrm{NaAlSi}_{3} \mathrm{O}_{8}\right)\right), 25 \%$ albite $\left(\mathrm{NaAlSi}_{3} \mathrm{O}_{8}\right), 4.5 \%$ biotite $\left(\mathrm{K}(\mathrm{Mg}, \mathrm{Fe})_{3}(\mathrm{OH}, \mathrm{F})_{2}\left(\mathrm{Si}_{3} \mathrm{AlO}_{10}\right)\right)$, and $1.5 \%$ accessories (tourmaline, zircon, fluorite, apatite, and topaz). Its heterogeneity hardens the pXRF analyses as the bedrock presents considerable variations in its composition. As the Erongo granite is a coarse-grained granite, the variations in its elemental composition vary at the millimetric scale. Therefore, at the scale of a painting the composition of the substrate is not homogeneous.

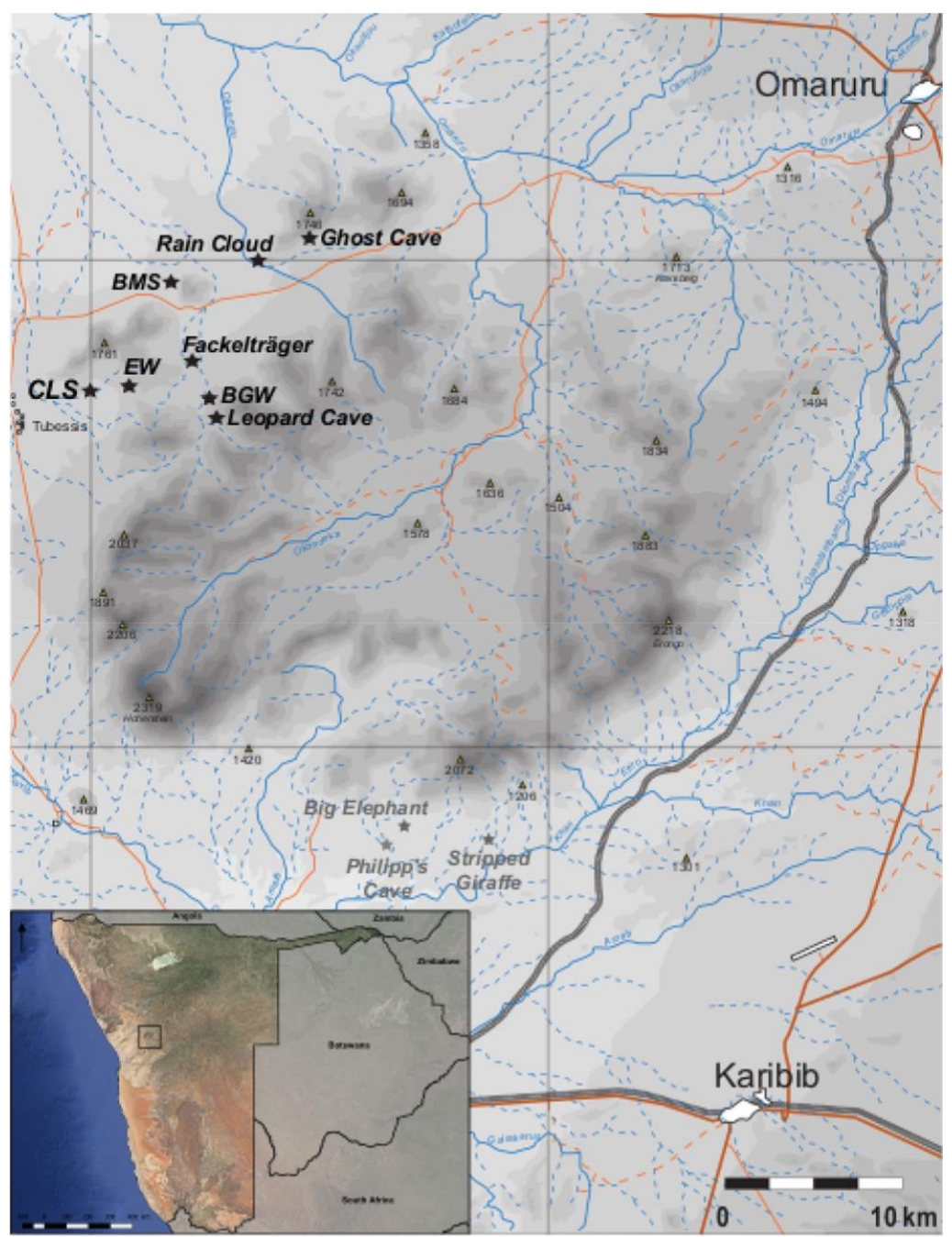

Fig. 1 Geographic location of the sites mentioned in the article with locations of the farms in which they are found. BMS, Black Man Shelter; BGW, Black Gnu Wall; CLS, Cycle of Life Shelter; EW, Elephant Wall; FT, Fackelträger; GC, Ghost Cave; LC, Leopard Cave; RC, Rain Cloud 


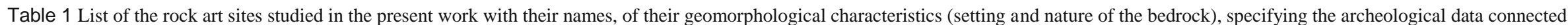

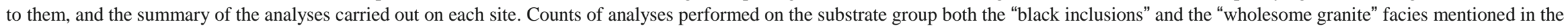
text. The KgEGg mentions is the code of the geological member of the granite, namely Erongo granite (Schreiber et al. 2010)

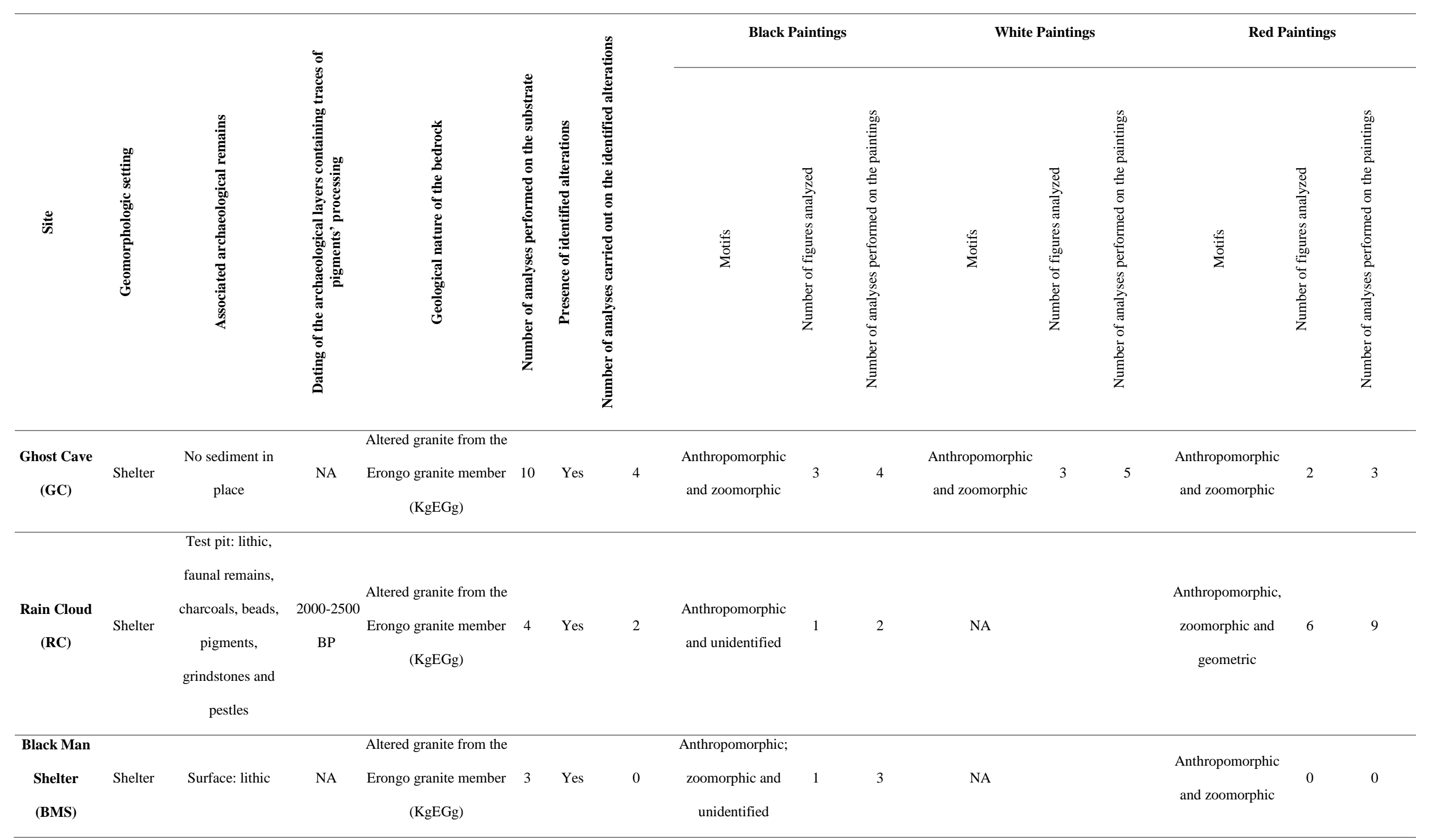




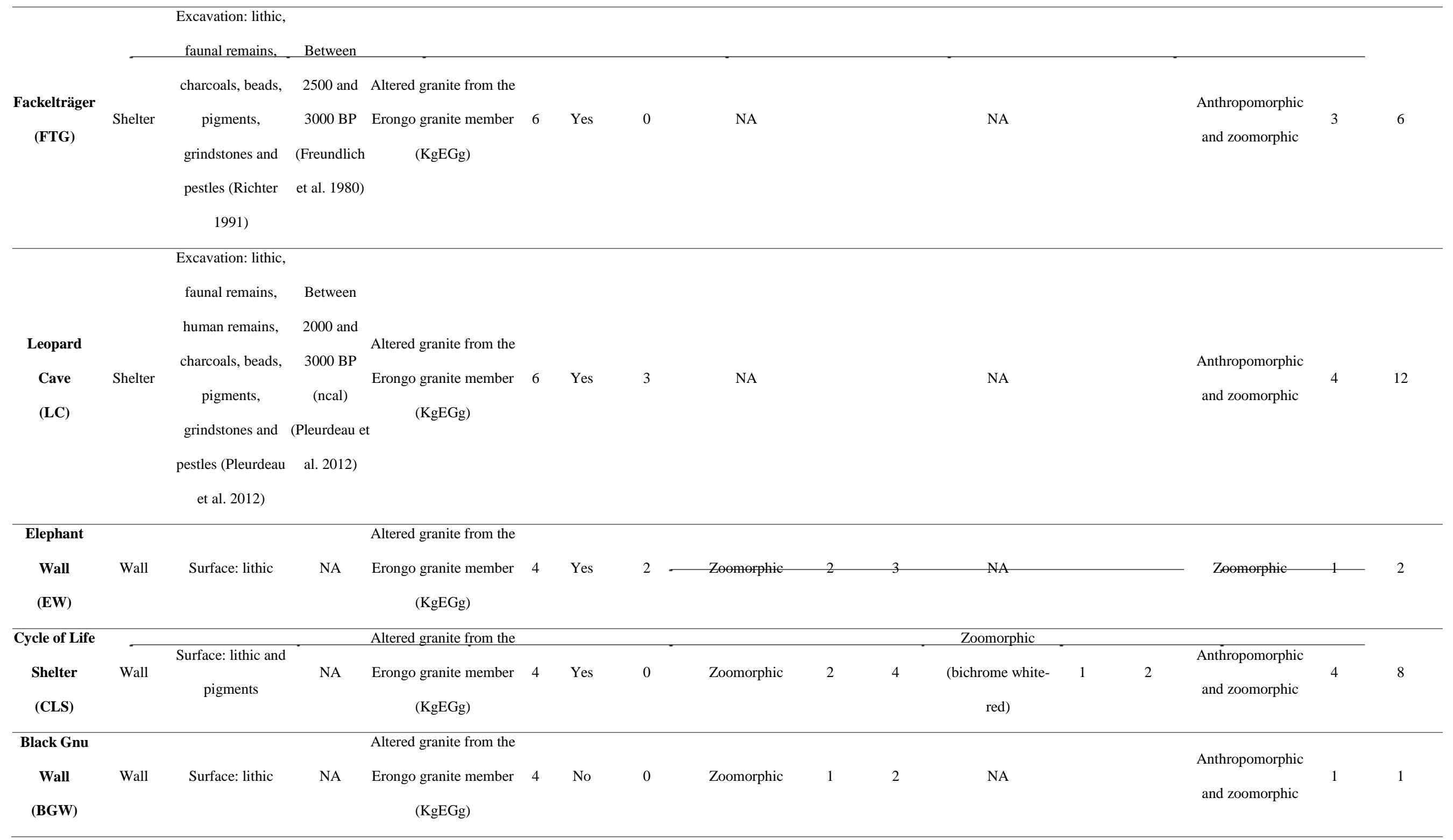




\section{Method}

Documentation of the sites and paintings was carried out thanks to numerous photographs and an extensive survey of the area (Nankela 2017). Close-up pictures of each painting element were performed with a Nikon D7100. They were then located within the panels and sites photos taken with both a Nikon D7100 and a Fujifilm AX-1. All photos were treated under DStretch ${ }^{\circledR}$ (Jon Harman) to ease the reading of faded representations.

All photos were flattened with a 10-scale within the DStretch ${ }^{\circledR}$. According to the color of the paintings to enhance, various DStretch ${ }^{\circledR}$ treatments were successfully applied: lds or lbk for the black painting, lrd for the white ones, and lds or crgb or ydt for the red ones (Harman 2008; Acevedo and Franco 2012).

In situ elemental analyses were carried out with an ELIO pXRF device (XGLab; Bruker) (Fig. 2a). Lithium-ion batteries provided the power supply necessary to run the analyses. The excitation source is a transmission tube with a rhodium anode providing a beam spot size of $1.2 \mathrm{~mm}$ in diameter, much smaller than the common handheld pXRF device from 3 to $8 \mathrm{~mm}$ in diameter. The pXRF system contains a Fast Silicon Drift X-ray Detector (SDD) with a 25-mm² active area. The geometry of the system allowed a working distance of $1.4 \mathrm{~cm}$ that precludes any damages of the rock painting from contact with the instrument (Fig. 2b). Two lasers and a digital microscope all run by the Elio software ensured an easy and efficient focalization of the beam spot on the surface to analyze. On the other hand, the air layer between the detector and the wall attenuated the low X-rays limiting reliable detection of elements under Al. Moreover, all spectra presented $\mathrm{K}$ and $\mathrm{L}$ peaks of rhodium $(\mathrm{Ka} 1=20,216 \mathrm{keV}$, $\mathrm{Ka} 2=20,074 \mathrm{keV}, \mathrm{Kb} 1=22,724 \mathrm{keV}, \mathrm{L} 1 \mathrm{M} 2=2,891 \mathrm{keV}, \mathrm{L} 1 \mathrm{M} 3=2,916 \mathrm{keV}, \mathrm{L} 2 \mathrm{M} 4=2,834 \mathrm{keV}$, and L3 M5 = 2,697 keV), imputable to the source, and $\mathrm{K}$ peaks of argon $(\mathrm{Ka} 1=2,954 \mathrm{keV}, \mathrm{Ka} 2=2,952 \mathrm{keV}$, and $\mathrm{Kb}=3,18 \mathrm{keV})$ due to the air layers between the detector and the sample.

Analyses were conducted at $20 \mathrm{kV}-200 \mathrm{~mA}$ for a 300-s live time. As mentioned by Roldán et al. (2010), López-Montalvo et al. (2014), and Gay et al. (2016), primary X-rays of pXRF spectrometers penetrate and excite the pictorial layers and the substrate on which they lie. Exciting the elements does not directly result in their detection. Indeed, to be detected, secondary Xrays emitted by the substrate have to pass through the pictorial and alterations layers with-out being absorbed. As pictorial layers and superficial alterations are only a few microns thick, pXRF measures indubitably bring information about the alteration, the pictorial layer, and the substrate at the same time. Consequently, performing analyses on the pigment and bare substrate at its vicinity is crucial to distinguish the signal from the dis-tinct layers, as already performed by most field rock art studies in other areas (e.g., Beck et al. 2012, 2014; Gay et al. 2015; López-Montalvo et al. 2014; Roldán et al. 2013).

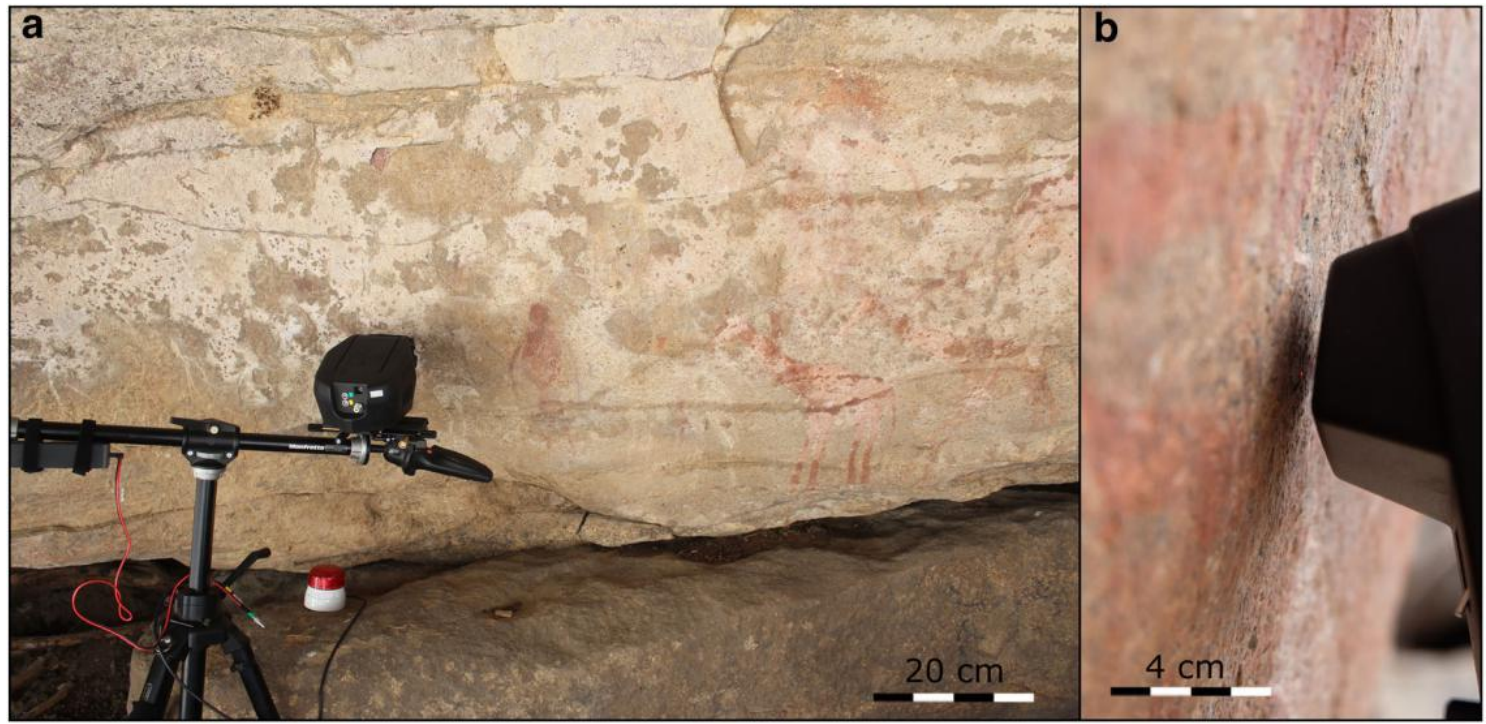

Fig. 2 The portable X-ray fluorescence ELIO spectrometer devise during the analyses of Ghost Cave paintings (a) and Cycle of Life shelter (b)

Increasing the primary X-ray energy also strengthened the probability of secondary excitation of light elements. As the penetration depth increased, more elements from the substrate emitted secondary X-rays. These radiations then interacted with light elements of the pictorial layer, leading to their overestimation. Time costly treatments can consider these considerations. It should be mentioned that previous studies have been performed on relatively homogeneous substrates (see Gay et al. 2015, 2016). The support of the Erongo rock art being heterogeneous, such treatments would require extensive time to provide few additional information compared to what is presented here. Therefore, we performed the analyses at $20 \mathrm{keV}$ to prevent uncontrolled bias imputable to secondary and tertiary excitations of the pictorial layers. Careful observations at the scale of each panel and each painting to ensure both the coherence and representativeness of the analyses always preceded the realization of any analysis. Each painting was analyzed at distinct points of the pictorial layer. Measures were performed on local spots 
presenting the thickest pictorial layer. The substrate composition was also investigated thanks to in situ measurements performed on the same area of the panel than each painting. In order to evaluate the composition variability of a heterogeneous substrate such as granite, further analyses were performed on different mineral grains visually identified, such as quartz and feldspar, and black inclusions such as biotite and/or tourmaline. The small beam spot size $(1.2 \mathrm{~mm})$ coupled with the microscope camera and positioning lasers of the Elio X-ray fluorescence spectrometer war-ranted controlled localized analyses on pictorial or substrate (bedrock or its alteration) areas. The digital microscope greatly helped to perform the analyses on the point presenting the thickest pictorial layer, considerably easing and improving the analyses.

The PyMCA software permitted to us to perform semi-quantitative analyses thanks to the calculation of the area of various elements peaks (Solé et al. 2007). Ternary diagrams, performed under the R software using the ggtern and ggplot2 packages, plot the areas obtained for sundry elements of interest thanks to PyMCA fitting software.

\section{Results}

\section{Substrate variability and alterations}

Visual observations of the painted panels distinguished three major facies hosting rock paintings: alterations deposits, black inclusions, and "wholesome granite". Examinations reveal that the granite bedrock is very rarely free of any alteration deposits. It has thus been difficult to discriminate easily the part of the variations of compositions directly related to the bedrock heterogeneity, from the one due to the alterations covering it.

Well-developed alterations deposits generally consist in coatings, more or less transparent, generally white but which can occasionally take the appearance of black or gray crusts in thicker areas. They exhibit distinct stages of development on the different panels studied. The thickest ones easily spotted and presenting about millimetric thickness constituted the facies of the alteration crusts. Due to their high development, they are hereafter referred to as the "altered substrates".

A second facies was defined by millimetric or sub-centimetric black inclusions easily identified on the field and constitutes another part of the substrate. In the present study, their analyses were performed to investigate the variability of the paintings substrate. Close observations of the painted panels prevented the analyses of pigment covering such inclusions.

Finally, the facies of the "wholesome granite" substrate refers to all the granite bedrock covered with thin, more or less transparent, alterations on which paintings could be found at the various sites.

In total, 52 analyses were carried out on the substrate and the alterations developing on it. Among them, 11 were per-formed on altered substrates, 2 on black inclusions within the substrate, and 39 analyses were carried out on substrates considered as "wholesome granite". Table 1 sums up the repartition of these measures at the different sites.

As alterations develop on both the granitic bedrock and the pictorial layer in various proportions from scarce to clearly visible all over the panel, it is crucial to first identify all the alterations present in the various sites to spot their presence in scarcer amounts, possibly underlying or overlying the pigments. In doing so, it prevents any over-interpretation about the composition of the paints.

In Omandumba area, four clearly visible alterations were analyzed within four sites (Fig. 3) and defined a first facies of support for the paintings. They all presented various macroscopic characteristics. Table 2 briefly sums up the characteristics of the alterations, the number of analyses performed on them, the identified characteristic elements, and the proposed mineralogical identification.

Among the facies of "altered substrates", two kinds of alterations are visible at the rock art sites considered in this study. These two kinds of alterations distinguish themselves out of their morphologic aspects: the leaks deposits and the crusts.

The leaks deposits correspond to banded coatings formed from fluids flows over the rock. Through their percolation into the surface of the bedrock, these fluids bring about the deposition of various minerals forming recognizable bands of alteration. At the sites we studied, these leaks correspond to the percolation of water or animal urine. Figure 3a provides a prime example of such weathering strip. Most of the time, they are opaque and present white to black colors, depending on the compounds depositing over the surface.

Crusts are common products of alteration, forming alterations deposits of various natures. Covering the open-aired Australian rock art, some materials such as gypsum (Chalmin et al. 2016, 2017; Green et al. 2017a, 2017b; Roberts et al. 2015), oxalates (Chalmin et al. 2017; Green et al. 2017a, 2017b; Roberts et al. 2015; Russ et al. 1999; Watchman 1991), or silicate (Roberts et al. 2015) deposits have been recorded. Their formation is complex and implies numerous processes (Watchman 1990).

Among the alterations analyzed here, two correspond to leaks deposits (Elephant Wall and Leopard Cave-Fig. 3a and b) and two to crusts (Rain Cloud and Ghost Cave-Fig. 3c and d). The former two clearly correspond to fluids leak-ages over the walls. The alteration of Elephant Wall corresponds to a smooth weathering lightly transparent strip formed by leakages over a wall overlooked by small vegetation (Fig. 3a). The alteration of Leopard Cave is much more different. It is the only one exhibiting a black coloration. It corresponds to a coarse-mineralized opaque vertical band following a white and yellow leak (Fig. $3 b$ ). 
The other two alterations correspond to crusts. Both of them are of whitish aspect, but present discrepancies in the size of the minerals aggregates forming them. While the one of Rain Cloud presents a fine-grained deposit of smooth aspect (Fig. 3c), the one of Ghost Cave exhibits a coarse-grained powdery one (Fig. 3d).

Figure 3e presents a $\mathrm{Fe} / \mathrm{Ca}-\mathrm{S} / \mathrm{Si}-\mathrm{Al}-\mathrm{K}$ tertiary diagram of all alteration analyses found at Elephant Wall, Leopard Cave, Rain Cloud, and Ghost Cave. Areas of the considered elements, obtained from the PyMCA fit, were used as estimators of the elemental contents of the alterations analyzed. The sum of the areas of six elements considered normalizes the contribution of each group of elements. The first axis corresponds to $\mathrm{Si}, \mathrm{Al}$, and $\mathrm{K}$, the main elements of the Erongo granite according to Blümel et al. (1979). As it will be detailed in the following section, calcium and sulfur have been identified preferentially on white alteration crust covering some parts of painting panels. Therefore, the second axis was conceived as an indicator of alteration thanks to the $\mathrm{Ca}$ and $\mathrm{S}$ content. The third axis coincides with Fe content. This third axis was first conceived as an indicator of iron oxide con-tent. It was initially built for red iron oxide pigments, but by definition corresponds to all phases rich in iron oxide.

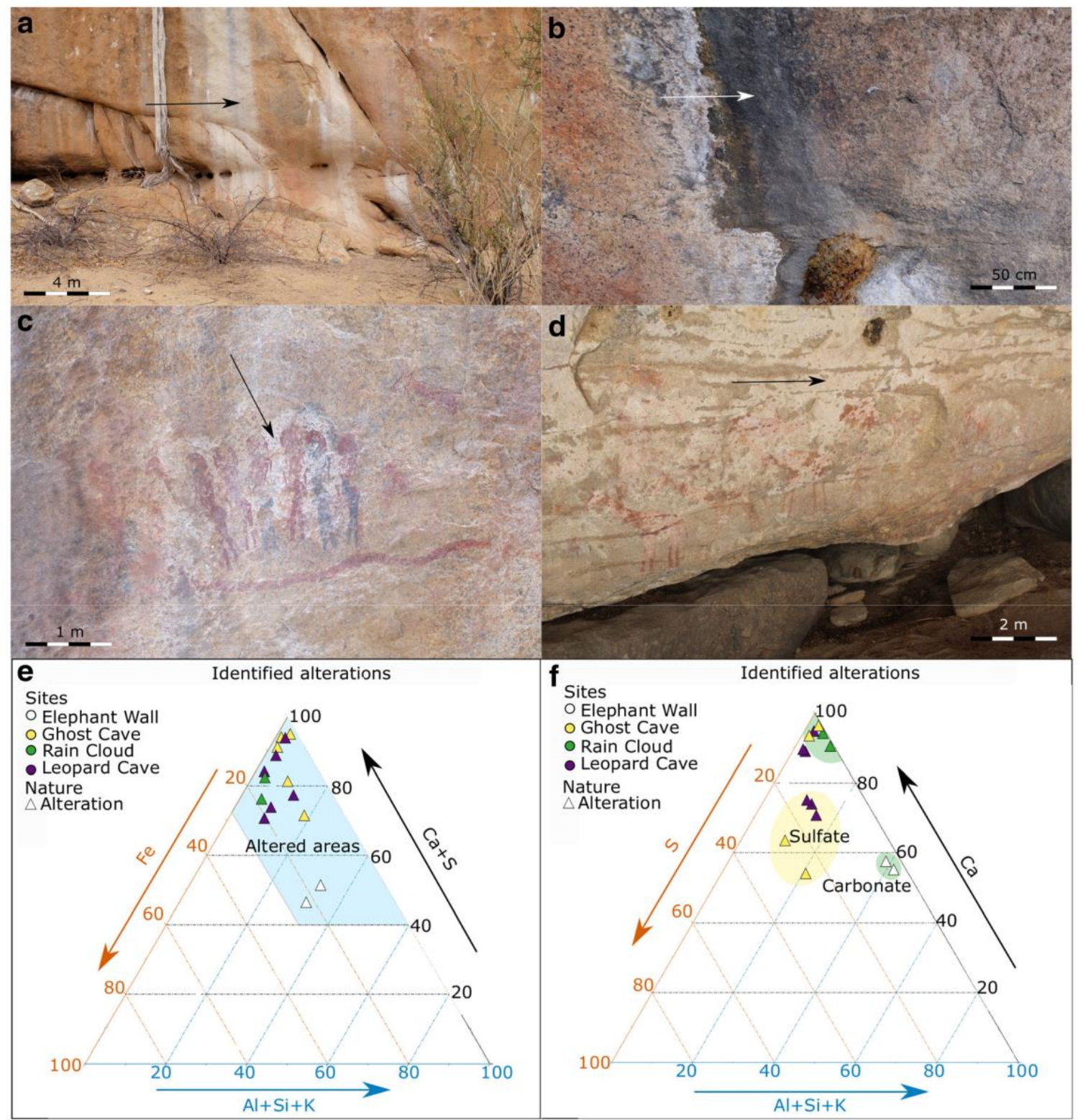

Fig. 3 Identified alterations. a-d Location and aspects at the various sites: Elephant Wall (a), Leopard Cave (b), Rain Cloud (c), and Ghost Cave (d). e, f Ternary diagrams to investigate the alterations of the substrate 
Table 2 Summary of the alterations aspect, the number of analyses performed on each of them, the identified elements imputable to the pictorial layer, and proposed identification

\begin{tabular}{|c|c|c|c|c|c|c|}
\hline 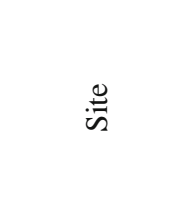 & 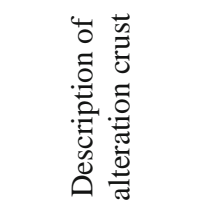 & 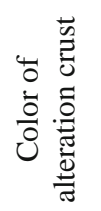 & 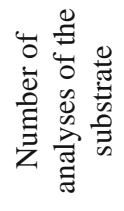 & 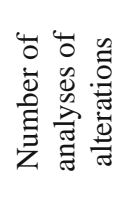 & 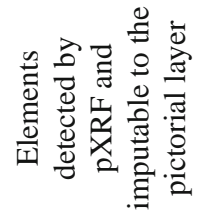 & 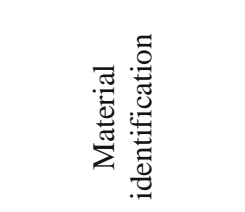 \\
\hline Leopard Cave & $\begin{array}{c}\text { Coarse- } \\
\text { mineralized } \\
\text { opaque thick } \\
\text { deposits }\end{array}$ & Black & 0 & 3 & $\mathrm{Ca}$ and $\mathrm{S}$ & $\begin{array}{c}\text { Calcium } \\
\text { carbonate / oxalate } \\
\text { and sulfate }\end{array}$ \\
\hline Elephant Wall & $\begin{array}{l}\text { Finely grained } \\
\text { lightly } \\
\text { transparent thin } \\
\text { deposits }\end{array}$ & White & 4 & 2 & $\mathrm{Ca}$ & $\begin{array}{c}\text { Calcium } \\
\text { carbonate or /and } \\
\text { oxalate }\end{array}$ \\
\hline Rain Cloud & $\begin{array}{l}\text { Thin coarse- } \\
\text { grained white } \\
\text { crust }\end{array}$ & White & 2 & 2 & $\mathrm{Ca}$ & $\begin{array}{c}\text { Calcium } \\
\text { carbonate or/and } \\
\text { oxalate }\end{array}$ \\
\hline Ghost Cave & $\begin{array}{c}\text { Thick coarse- } \\
\text { grained white } \\
\text { crust }\end{array}$ & White & 3 & 4 & $\mathrm{Ca}$ and $\mathrm{S}$ & Calcium sulfate \\
\hline
\end{tabular}

It is safe to conclude that elemental areas considered are an easy estimator of the elemental composition of the alterations. However, it does not correspond to the real content of each element due to matrix and grains issues. Proper elemental quantification is not possible in the present case. The heterogeneity of the materials considered, the presence of multiple layers of various thicknesses does not allow a proper quantification of elemental composition of the alterations. Therefore, estimating the contribution of each element to the spectra collected is likely a good way to evaluate the diversity of the alterations nature. Of course, contributions of light elements such as $\mathrm{Si}$ and $\mathrm{Al}$ are underestimated to the profit of heavier ones such as $\mathrm{Fe}$ or $\mathrm{Ca}$. Treated with caution, these data provided good ideas of the diversity of the alterations found at the sites considered in our study.

Figure $3 \mathrm{e}$ presents only the results obtained from the four alterations considered. As they were collected from the analyses of "altered areas", they defined an area of high alteration, plotted in blue. This area corresponds to a Ca and S contribution of at least $40 \%$. Within it, two major trends appeared the "thin" alteration of Elephant Wall which Ca and S contributions fall around $45 \%$ and the "thick" ones of the three other sites, for which the Ca and S contributions is of at least 65\%. As mentioned earlier, the Elephant Wall alteration is lightly transparent, while the other ones are opaque, supporting a difference of alteration thickness. Thinner thickness of the alteration crust is here exhibited by the lighter $\mathrm{Ca}$ and $\mathrm{S}$ contribution than for the other alterations deposits.

To differentiate further the alterations according to their nature and not only out of their thickness, Fig. $3 \mathrm{f}$ presents another similarly built $\mathrm{S} / \mathrm{Ca} / \mathrm{Si}-\mathrm{Al}-\mathrm{K}$ ternary diagram. The first axis corresponding to the main elements of the granite ( $\mathrm{Si}, \mathrm{Al}$, and $\mathrm{K}$ ) was maintained, whereas calcium and sulfur contents where splat in other axes to differentiate the different possible white pigments between calcium sulfate pigments and calcium carbonate or oxalate ones. The second axis corresponds to the area of calcium peak, while sulfur built the third axis.

As visible in Fig. 3f, in situ elemental measures distinguish two kinds of calcium-rich alterations. The first group corresponds to the alterations of Elephant Wall and Rain Cloud. The pXRF analyses show that the finely grained alterations present high contents of $\mathrm{Ca}$ with no other detectable elements (elements heavier than $\mathrm{Al}$ ) not imputable to the granitic bed-rock. Therefore, the alteration corresponds to calcium-rich de-posits that are well-known rock art alterations and usually correspond to calcite $\left(\mathrm{CaCO}_{3}\right)$ or calcium oxalates $\left(\mathrm{Ca}\left(\mathrm{C}_{2} \mathrm{O}_{4}\right) \cdot \mathrm{x}\left(\mathrm{H}_{2} \mathrm{O}\right)\right)$. Their identification is of high interest since they can provide supports for direct dating of rock paintings they can cover (Aubert et al. 2007; Mazel and Watchman 2003; Plagnes et al. 2003 ; Russ et al. 1996, 1999). Their dating is the most recent development in rock art research as the literature shows it (García-Diez et al. 2013; Hoffman et al. 2016, 2017, 2018; McDonald et al. 2014; Pike et al. 2012; Sanchidrian et al. 2017; Shao et al. 2017; Valladas et al. 2017). Thus, it may provide a terminus ante quem of the time of realization of the artworks. Investigations are currently carried out to characterize further these deposits and test the possibility of dating these fine crusts of oxalate alterations in the Erongo region.

At Ghost Cave, the pXRF spectra highlight a high content in $\mathrm{Ca}$ and $\mathrm{S}$ with no other element solely imputable to the alteration. This alteration is mainly composed of calcium sulfate $\left(\mathrm{CaSO}_{4}\right)$, a well-known alteration deposit in rock art in arid and 
semi-arid climatic environments (Chalmin et al. 2016; Roberts et al. 2015; Watchman 1990). This second kind of alteration is also present at Leopard Cave.

Analyses performed on micro-samples from various rock art areas have shown the complexity of the alterations developing over pictorial layers (Huntley 2012). They are usually complex, and gypsum often bears minor phases of calcium-rich minerals, though in insufficient quantities to be detectable to pXRF analyses. Main various compounds present in the area analyzed can be identified from pXRF experiments if they present distinguishable characteristic elements. In case of a mixture, it can be hard to identify the minor phases.

Examinations reveal that the granite bedrock is rarely free of any alteration deposits. Analyses performed on in situ identified alterations are crucial to investigate the variability of the substrate. Their identification allowed defining a first facies, later completed by two others: iron-rich inclusions and "wholesome granite".

In order to visualize the variation of the substrate, Fig. 4 presents a $\mathrm{Fe} / \mathrm{Ca}-\mathrm{S} / \mathrm{Al}-\mathrm{Si}-\mathrm{K}$ ternary diagram for the substrates analyses of various sites studied here (Elephant Wall, Ghost Cave, Rain Cloud, Leopard Cave, and Fackelträger). Figure 4 highlights the high variability of the substrate. The analyses performed allowed defining three sundry facies: the altered sector already defined thanks to the analyses of the alterations (in blue), a zone of analyses of iron-rich inclusions (in gray), and a "wholesome granite" pole (in orange).

Figure 4 clearly evidences the high occurrence of alterations over the granite. Indeed, most of the analyses of the substrate reveal the relatively high amount of $\mathrm{Ca}$ and $\mathrm{S}$, higher than the amounts expected for the granite described by Blümel et al. (1979). Numerous analyses of the substrate fell within or close to the area of the alterations thanks to clearly identified alterations. It reveals the important development of alterations over the panels considered in our study.

The second facies corresponds to millimetric or sub-centimetric black inclusions imputable to the presence of biotite in Erongo granite as mentioned by Blümel et al. (1979). Two of such inclusions were analyzed on Leopard Cave and Elephant Wall panels to investigate the substrate variability. Their analyses reveal their high Fe content (Fig. 3). These inclusions largely drove the granite Fe content variability and allowed the definition of the iron-rich inclusions pole within the ternary (Fig. 4). The black inclusions can draw severe limits in the interpretation of the PXRF spectra of the pictorial analyses. As it will later be discussed in the general discussion, however, careful observations of the analyzed area prevent from analyzing pigments lying on such iron-rich inclusions.

The numerous pXRF measurements evidenced other high variabilities of the composition of the substrates on which are lying the paintings investigated. Apart from the Fe variations, the main variations were observed for $\mathrm{Al}, \mathrm{Si}, \mathrm{K}, \mathrm{Ca}$, and $\mathrm{S}$.

All the analyses of the substrates not falling within the two previous facies constituted the "wholesome Erongo granite". Within this area, there is a large variability as exhibited in Fig. 4. It reinforces the importance of analyzing the substrate next to the paintings considered, as no general trend can be sorted out for the substrate for a site as exhibited for Rain Cloud.

From the analysis of the substrates, it is clear that the Erongo granite exhibits a large heterogeneity both driven by the nature of the bedrock and the alterations covering it. Alterations are also important as they can develop over the pictorial layer and attenuate the secondary X-rays, consequently introducing bias in the analyses and identification of the pigment compositions. The various alterations identified during our study helped us to identify the various pigments analyzed.

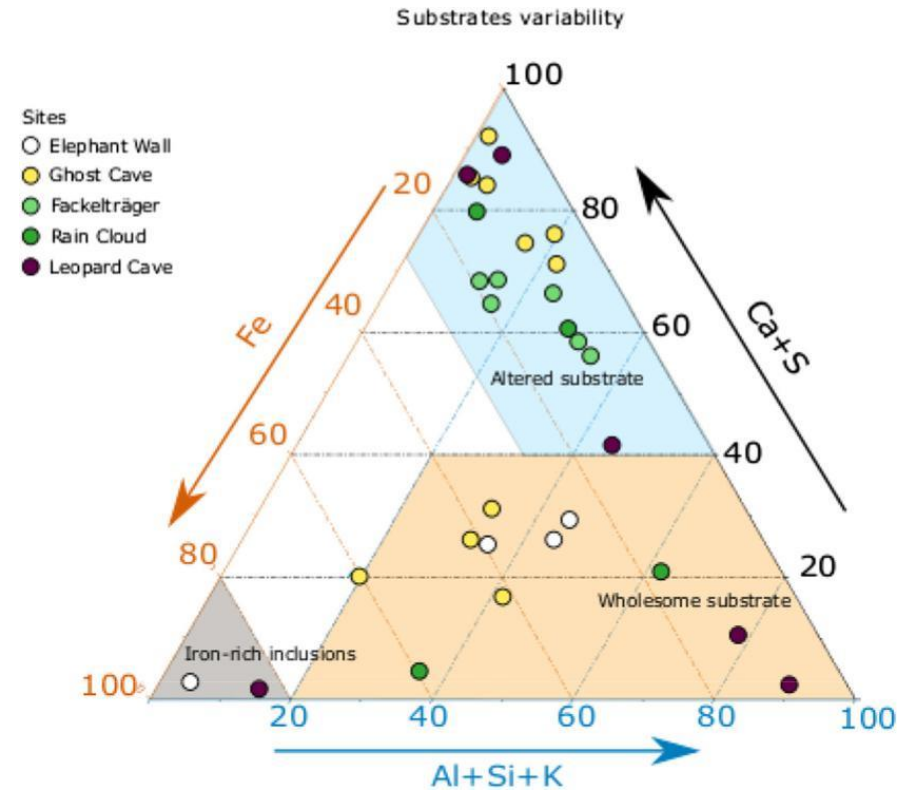

Fig. 4 Ternary diagram of the substrates at the various sites investigated in this work. The orange area identifies the analyses of "wholesome" Erongo granite, the gray one the iron-rich inclusions identified as such on the field, and the blue one the highly altered substrates 
Compositions of three different kinds of pigments were investigated by XRF: black, white, and red pigments. Table 3 sums up the localization, nature of figures, and the identification of pigment used according to the color of the figures.

For each analysis, the qualitative composition was established from XRF spectra after treatment using PyMCA software. This step allowed verification of the good adequacy between the experimental and theoretical fit and thus ensuring proper identification of all elements.

In total, nine major or minor elements ( $\mathrm{Al}, \mathrm{Si}, \mathrm{P}, \mathrm{S}, \mathrm{K}, \mathrm{Ca}, \mathrm{Ti}, \mathrm{Mn}$, and Fe) could be used to identify the composition of the various pictorial layers. All other elements appeared in so various quantities that it was not possible to exploit them. Trace elements could not be used due to their high variability within the substrate and the low detection limit of the equipment in the present conditions of use. According to the analyses performed on the substrate and alterations, some elements can be mainly attributed to the granitic bedrock ( $\mathrm{Al}, \mathrm{Si}$, and $\mathrm{K}$ ) and the alterations $(\mathrm{Ca}, \mathrm{S})$, while other elements are likely to bring information about the pigments.

${ }^{1}$ Table 3 Summary of the paintings analyzed, their localization, the nature of the figures, their color, the identified characteristic elements, and proposed identification of the pigments used to perform the paintings. ${ }^{1}$ Red painting underlying (see text)

\begin{tabular}{|c|c|c|c|c|}
\hline Site & Motif (number of figures analyzed) & Color & $\begin{array}{l}\text { Characteristic elements of the } \\
\text { pictorial layer detected by pXRF }\end{array}$ & $\begin{array}{l}\text { Interpreted pigment } \\
\text { identification }\end{array}$ \\
\hline Black Gnu Wall & Gnu (1) & Black & None & Carbonaceous black \\
\hline Black Man Shelter & Anthropomorphic (1) & Black & None & Carbonaceous black \\
\hline Cycle of Life Shelter & Bovid (2) & Black & None & Carbonaceous black \\
\hline Elephant Wall & Equid (2) superimposed on red elephant & Black & $\mathrm{Fe}^{1}$ & Carbonaceous black \\
\hline Ghost Cave & Giraffe (1) & Black & None & Carbonaceous black \\
\hline Ghost Cave & Bovid (1) & Black & None & Carbonaceous black \\
\hline Ghost Cave & Anthropomorphic (1) & Black & $\mathrm{Ca}$ and $\mathrm{S}$ & Carbonaceous black \\
\hline Rain Cloud & Bichrome anthropomorphic (1) & Black & None & Carbonaceous black \\
\hline Cycle of Life Shelter & Bichrome giraffe (1) & White & $\mathrm{Ca}$ & Calcium carbonate or oalate \\
\hline Ghost Cave & Ostrich (1) & White & $\mathrm{Ca}, \mathrm{S}$, and $\mathrm{P}$ & Apatite and calcium sulfate \\
\hline Ghost Cave & Ghost (2) & White & $\mathrm{Ca}, \mathrm{S}$, and $\mathrm{P}$ & Apatite and calcium sulfate \\
\hline Black Gnu Wall & Lion (1) & Red & $\mathrm{Fe}$ & Iron oxide \\
\hline Cycle of Life Shelter & Bichrome giraffe (1) & Red & $\mathrm{Fe}$ & Iron oxide \\
\hline Cycle of Life Shelter & Bovid (1) & Red & $\mathrm{Fe}$ & Iron oxide \\
\hline Cycle of Life Shelter & Springbok (1) & Red & $\mathrm{Fe}$ & Iron oxide \\
\hline Cycle of Life Shelter & Anthropomorphic (1) & Red & $\mathrm{Fe}$ & Iron oxide \\
\hline Elephant Wall & Elephant (1) & Red & $\mathrm{Fe}$ & Iron oxide \\
\hline Fackleträger & Unidentified (1) & Red & $\mathrm{Fe}, \mathrm{Ti}$, and $\mathrm{Mn}$ & Iron oxide \\
\hline Fackleträger & Giraffe (1) & Red & $\mathrm{Fe}$ & Iron oxide \\
\hline Fackleträger & Bovid (1) & Red & $\mathrm{Fe}$ & Iron oxide \\
\hline Ghost Cave & Anthropomorphic (2) & Red & $\mathrm{Fe}$ & Iron oxide \\
\hline Leopard Cave & Giraffe (1) & Red & $\mathrm{Fe}$ & Iron oxide \\
\hline Leopard Cave & Springbok (1) & Red & $\mathrm{Fe}$ & Iron oxide \\
\hline Leopard Cave & Unburied traces (1) & Red & $\mathrm{Fe}$ & Iron oxide \\
\hline Leopard Cave & Strip (1) & Red & $\mathrm{Fe}$ & Iron oxide \\
\hline Rain Cloud & Bichrome anthropomorphic (2) & Red & $\mathrm{Fe}$ & Iron oxide \\
\hline Rain Cloud & Giraffe (1) & Red & $\mathrm{Fe}$ & Iron oxide \\
\hline Rain Cloud & Cloud (1) & Red & $\mathrm{Fe}$ & Iron oxide \\
\hline Rain Cloud & Anthropomorphic (2) & Red & $\mathrm{Fe}$ & Iron oxide \\
\hline
\end{tabular}

\section{Black paintings}

Among the ten black rock paintings analyzed within six sites (Table 3), two different kinds of black pigments can be distinguished. The first group corresponds to all black pigments analyzed but the one of the black anthropomorphic figure of Ghost Cave, leaving this one as the sole occurrence of the second group.

The pigment employed to draw the gnu at Black Gnu Wall (Fig. 5) here illustrates the first group. For this group, the spectra of the pictorial layer and of the granitic bedrock are indistinguishable (Fig. 5b). There is no difference of elemental com-position 
between the two materials, sweeping away the possible use of manganese oxide pigment. At Ghost Cave, a black giraffe and a black bovid present similar features. Consequently, we can safely conclude that the pigment used there must be carbonaceous black. Lack of phosphate inside the pictorial layer suggests the pigment of the black gnu not to be bone black (Roldán et al. 2013). Black anthropomorphic figure at Black Man Shelter, black zoomorphic representations at Cycle of Life Shelter, and bichrome anthropomorphic figures at Rain Cloud present the same features than the Black Gnu.

For the black anthropomorphic figure of Ghost Cave, the composition of pigment is slightly different from the substrate analyses performed close to the figure. The spectra of the pictorial layer exhibit higher content of calcium, sulfur, and phosphorus and lower ones of aluminum, silicon, and potassium than the substrate (Fig. 5d). As there is no pure black pigment composed of calcium, sulfur, and phosphorus, to our knowledge, the painting considered here must be seen as a complex system with several layers or a mixture associated to black carbon. These black figures are located on a small block at the bottom of a wall hosting white and red paintings and a white alteration, identified as calcium sulfate as previously presented (Table 2). It is here thought that the calcium sulfate alteration is also present locally on the wall underneath the pictorial layer and interferes with the analysis of the black pictorial layer. As observations with the digital microscope did not evidence any deposit over the black paint, calcium sulfate must be present under the black painting layer. The presence of calcium sulfate could also derive for its use as an extender. Literature largely evokes such a preparation in European Paleolithic caves context (Clot et al. 1995; Clottes et al. 1990; Menu and Walter 1996). The presence of phosphorus can suggest that the pigment used is not charcoal, but possibly bone black (20\% carbon, $\left.80 \% \mathrm{Ca}_{10}(\mathrm{OH})\left(\mathrm{PO}_{4}\right)_{36}(\mathrm{OH})_{2}\right)$. Another possible source of phosphorus could be P-rich mineral like apatite that can derive from taphonomical alteration of bedrock. Ward et al. (2001) highlighted that among taphonomical processes leading to phosphorus enrichment, bird droppings and their degradation by microorganisms are essential. Bird and animal droppings are common features covering walls of the Erongo granite, making dropping alterations a possible origin for the P detected during our analyses at Ghost Cave.

Phosphorus was detected on the two spots analyzed on this figure and was not detected anywhere else on this large panel. Although we cannot exclude the presence of apatite-like minerals, specifically in this area of the painted panel, this result can suggest the presence of bone black. However, pXRF data appear to be non-conclusive to identify the nature of the pictorial layer on such altered substrate. Further, pXRF will not provide further information but transmission electron micros-copy (TEM) analysis on micro-sampling could help to con-firm or infirm the presence of bone black as shown by Chadefaux et al. (2008) in cave context.

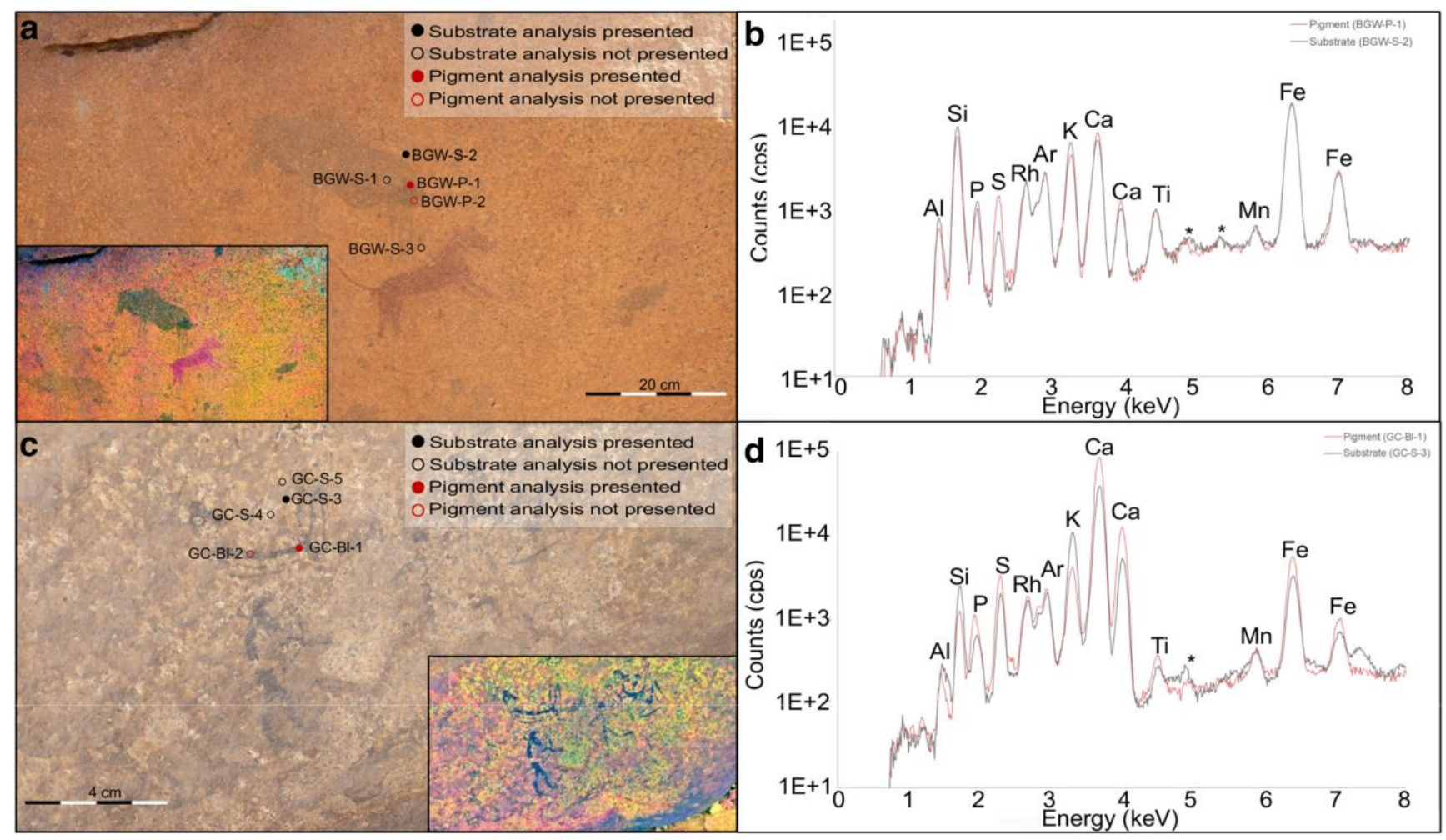

Fig. 5 Location of analyses performed on the back gnu at Black Gnu Wall (a) and for the black anthropomorphic figure of Ghost Cave (c). D-stretched treatments were added in insert to enhance visualization of the figures. b, d Examples of pXRF spectra of the pigments (red) and support (black) for each panel. Escape peaks are labeled with a *. Non-labeled peaks correspond to elements for which the presence could not be assessed due to the variability they exhibit on the different spectra acquired 
Observations of the black equids representations of Elephant Wall highlighted their superimposition over red elephant figures. As the black pigment present on the site appears as a matte layer, it was thought to be composed of manganese oxide. The spectra collected from the analyses performed on black pigments with apparent low red pigment content did not exhibit any manganese or phosphorus, though presented iron signal. Analyses of the black equids of Elephant Wall permit-ted to exclude the use of manganese oxide as a pigment on the black paintings analyzed. Although strictly not conclusive, as no iron-based black prehistoric pigment is yet known to be used in Southern Africa, it is thought that the black pigment is carbonaceous but spoiled by the underlying red pigments. Further investigations, such as in situ Raman analyses, should confirm this last assumption.

\section{White paintings}

Although scarce, the white paintings present an interesting variability. In the two sites hosting white representations, Cycle of Life shelter and Ghost Cave, the pictorial layers exhibit distinct compositions (Fig. 6).

Ternary diagrams presented in Fig. $6 \mathrm{a}(\mathrm{Fe} / \mathrm{Ca}-\mathrm{S} / \mathrm{Si}-\mathrm{Al}-\mathrm{K})$ and $6 \mathrm{~b}(\mathrm{~S} / \mathrm{Ca} / \mathrm{Si}-\mathrm{Al}-\mathrm{K})$ locate the white pigment analyses within the areas previously defined. Identified alterations and substrate analyses of these two sites (Cycle of Life Shelter and Ghost Cave) are also presented to allow a direct comparison of the analyses.

In Fig. 6a, the Fe/Ca-S/Si-Al-K ternary diagram, analyses of the white pictorial layer of Cycle of Life Shelter, its Ca-S contribution is much higher (around 60\%) than the ones of its substrate (below 20\%). As for the pigments of Ghost Cave, they present similar $\mathrm{Ca}-\mathrm{S}$ contribution than those of the alterations and some of the apparent bedrock analyzed at the site. It prevents all distinction between the pigments and its substrate.

In Fig. 6b, the $\mathrm{S} / \mathrm{Ca} / \mathrm{Si}-\mathrm{Al}-\mathrm{K}$ ternary diagram, the Cycle of Life Shelter pigments show a $\mathrm{S}$ contribution lower than $5 \%$ but a $\mathrm{Ca}$ one of around $75 \%$, while its substrate presents the same contribution of S and a Ca one below $40 \%$. In the case of the white pigments of Ghost Cave, the S contribution is around $17 \%$ and the Ca around $80 \%$, similar to the ones calculated for the altered substrate analyzed at the site.

Combined, Fig. 6a and b exhibit the difference between the two white pigments considered here. Indeed, although they both present relatively high Ca content, the white pigments analyzed for the giraffe on Cycle of Life Shelter and the ostrich on Ghost Cave panels present distinct compositions, especially in sulfur, compared to their substrate. The difference of $\mathrm{S}$ and Ca contribution highlighted in Fig. 6b supports the presence of a carbonated white pigment at Cycle of Life Shelter and of calcium sulfate at Ghost Cave. Specific analyses of the pXRF spectra confirm this hypothesis: as the two sites presented distinct pictorial materials, Fig. $6 \mathrm{c}$ to $6 \mathrm{f}$ locate the various analyses and exemplify the pXRF data obtained for each site. To ease the reading, only two pXRF spectra are presented for each site: one for the pictorial layer and one for the substrate (Fig. 6d, f). The bichrome giraffe figure of the Cycle of Life Shelter (Fig. 6c) presented higher content of calcium when compared to its support (Fig. 6d). No other detectable element could be associated undoubtedly to the pictorial layer. The results suggest the presence of calcium carbonate. Calcium carbonate $\left(\mathrm{CaCO}_{3}\right)$ is a material extensively found in natural compounds such as mineral calcite $\left(\mathrm{CaCO}_{3}\right)$, eggshells ( $80 \%$ to $96 \% \mathrm{CaCO}_{3}$, remaining organics), or calcrete (cemented calcium carbonate sediment) (Hincke et al. 2012; Jacobson et al. 1994). As these materials can be found all over Namibia, their use does not bring crucial information about ancient populations' procurement strategies of raw colored material. SEM microsample analyses are needed to bring more insights into the techniques used to produce this white pigment.

The white ostrich and ghosts at Ghost Cave present similar spectra; therefore, only the spectra collected from the ostrich are presented here. The figures lay next to white alterations looking like the pictorial layer (Fig. 6e). Spectra of the paint presented higher content of calcium and phosphorus, similar signal of sulfur, potassium, and silicon than those of the alteration (Fig. 6f). It indicates that the pigment deposit is com-posed by calcium sulfate $\left(\mathrm{CaSO}_{4}\right)$ as the alterations nearby and calcium phosphate.

It is tempting to say that the alterations could have been used as a raw material to produce the paint at Ghost Cave. However, there is a crucial discrepancy between the white representations material and the alterations: the content of phosphorus. Pictorial layers presented higher amount of phosphorus than the alterations, and the substrate never exhibits such levels of phosphorus, permitting us to associate the phosphorus only to the paint. The phosphorus contained in the pictorial layer could be imputed to various possibilities such as, for example, a phosphorus-rich mineral, probably apatite mixed, willingly or not, with the calcium sulfate alteration or an apatite $\left(\mathrm{Ca}_{5}\left(\mathrm{PO}_{4}\right)_{3}(\mathrm{OH}, \mathrm{Cl}, \mathrm{F})\right)$ extender as reported in literature (Clot et al. 1995; Clottes et al. 1990; Menu and Walter 1996), or even the biodegradation of an extender. Determining the origin of the apatite cannot solely rest over pXRF analyses. Such complex situations need the use of complementary methods to provide better identification of the various layers in presence. 


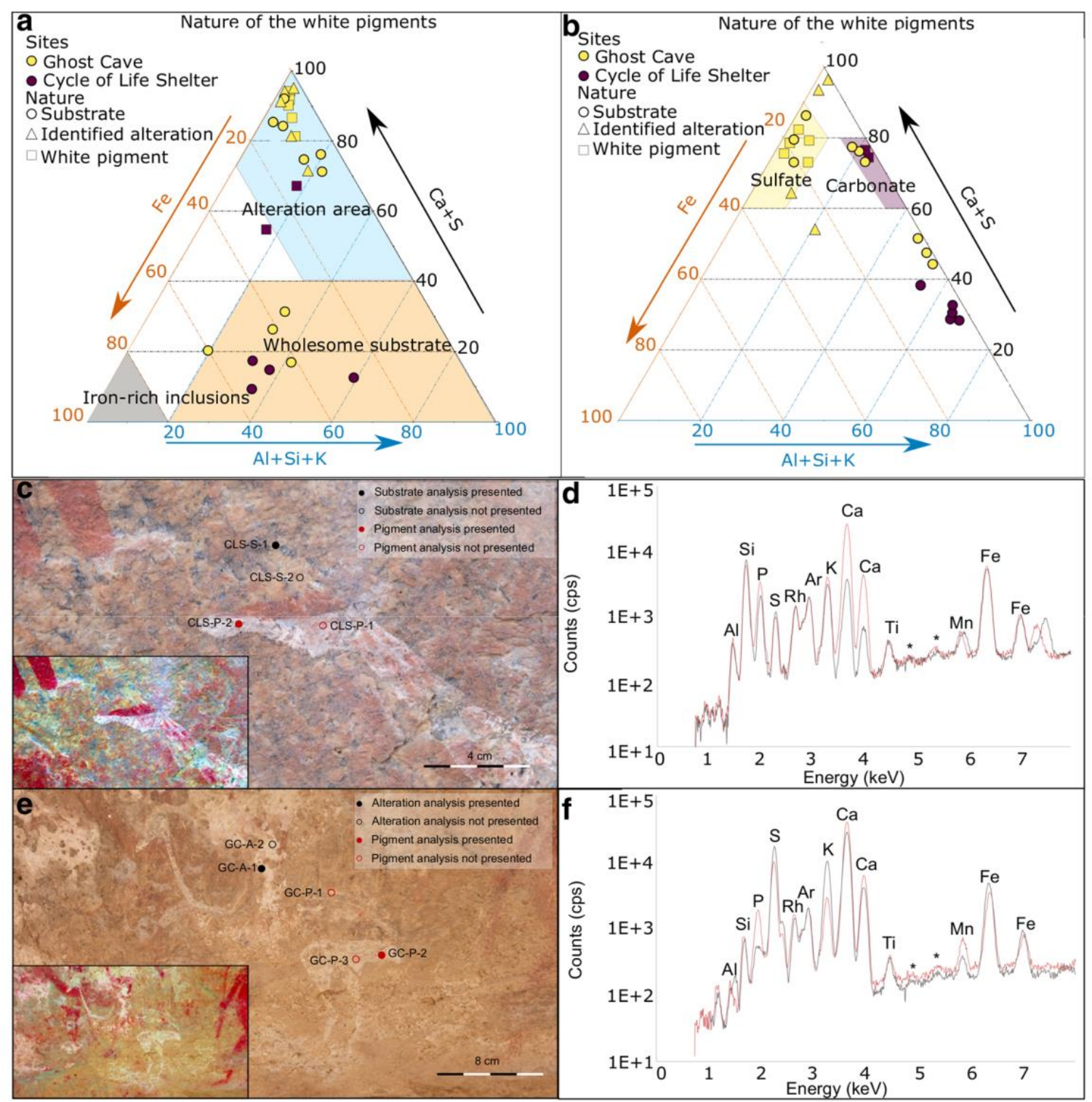

Fig. 6 a, b Ternary diagrams to investigate the nature of the white paintings. Location of the analyses performed on the bichrome giraffe of the Cycle of Life Shelter (c) and of the white ostrich of Ghost Cave (e). d Stretched treatments were added in insert to enhance visualization of (d) and (f): pXRF spectra of the pigments (red), alterations and support (black) for each panel. Escape peaks are labeled with a *. Non-labeled peaks correspond to elements for which the presence could not be assessed due to the variability they exhibit on the different spectra acquired.

\section{Red paintings}

Unsurprisingly, all the red paintings analyzed exhibited higher content of iron than their substrate, confirming the use of iron oxides as a red pigment (Fig. 7). It endorses the generally acknowledged use of iron oxide as red pigment in the scientific literature about San rock art (Prinsloo et al. 2008, 2013). As Leopard Cave and Fackelträger sites exemplify well the results obtained from all other sites, and to ease the reading of the following part, it was decided to present only the results of the seven paintings found at these two sites and not all 21 red paintings.

Figure 7 presents $\mathrm{Fe} / \mathrm{Ca}-\mathrm{S} / \mathrm{Si}-\mathrm{Al}-\mathrm{K}$ ternary diagrams of the red paintings analyzed during this work on the two specific sites of Leopard Cave (Fig. 7a) and Fackelträger (Fig. 7b). Each point represents an analysis. The nature of the materials (red pigments, wholesome substrate, iron-rich inclusion, or alteration of the substrate) and of the motif are detailed. All of these figures locate the results within the previously defined areas of alterations, iron-rich inclusions, and "wholesome granite". According to the analyses performed on the red paintings, various red pigments were defined when the pigments distinguished itself from its substrate.

Visual observations allowed preventing analyses of red pigments lying over black iron-rich inclusions. In Fig. 7, all red paintings analyzed present higher content of iron than their substrate, if iron-rich inclusions are to be put aside for a later discussion. 

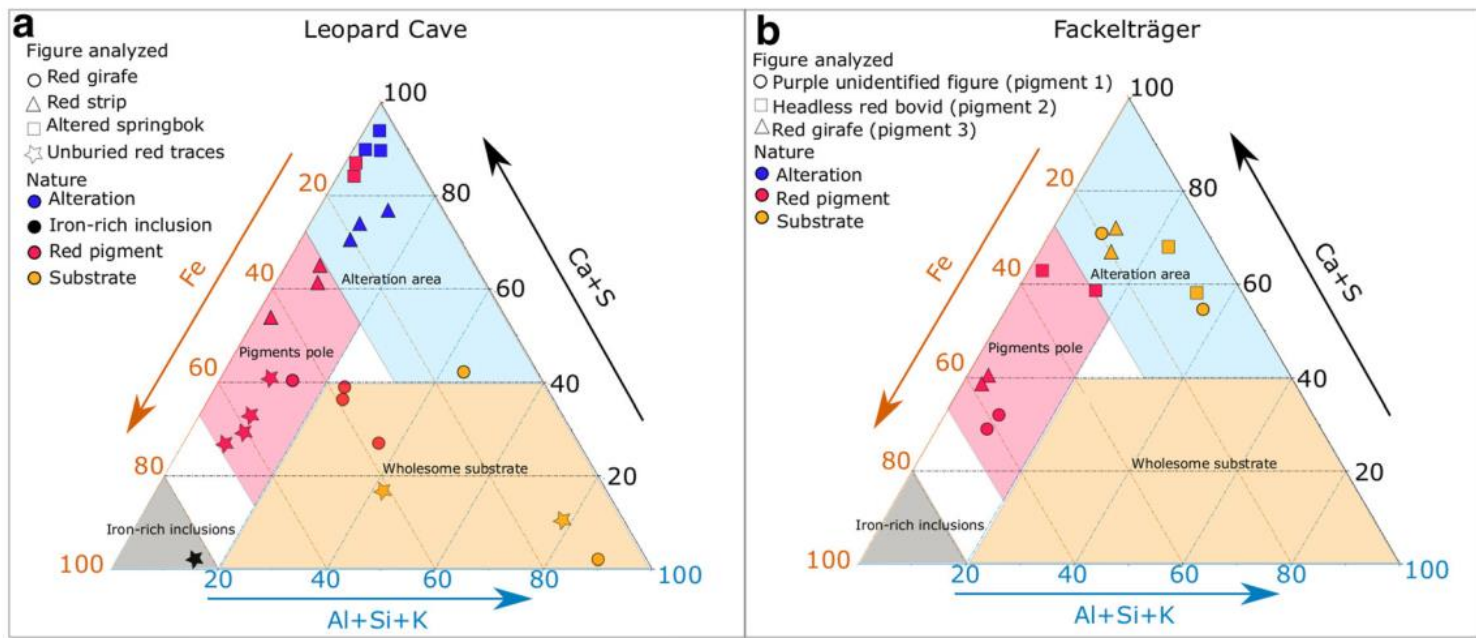

Fig. 7 Ternary diagram of the substrates, alterations, and red pigments at the various sites investigated in this work. Blue areas correspond to the highly altered materials zone, the red one to the pigments, orange the wholesome Erongo granite, and gray the iron-rich inclusions

At Leopard Cave, among all the red paintings and traces of pigments, four areas were analyzed: the red strip, the red giraffe, the unburied red traces, and the altered springbok. Most of them either are washed out or severely altered (Fig. 8). These different areas present different state of visual preservation. The red giraffe painting is a well-preserved red representation with the best conservation state at this archeological site (see Fig. 8a and b). The red strip is a band of washed red pigment found at the bottom of the wall just above the datum line (Fig. 8a). Although alterations developed nearby to it, it seems the representation itself is less affected by alterations. The altered springbok is a red figure from which only the back legs of what could be a springbok are still visible (Fig. 8c). The alteration covering it is the black one previously presented and composed of calcium sulfate. The last area investigated corresponds to scarce red tint on the wall discovered following the excavation carried out near the wall (Fig. 8). For us, it presented an opportunity to test the possibility of detecting and confirming the presence of iron oxide on a severely altered substrate in an archeological context.

In Fig. 7a, presenting the analyses performed at Leopard Cave, three groups of pigments appear: the ones of the altered springbok, the ones of the red strip, and the ones of the red giraffe and of the unburied red traces.

The analyses of the pigments of the altered springbok completely fall within the alterations area, with a high contribution of $\mathrm{Ca}-\mathrm{S}$ (above 80\%). Although its iron contribution is a bit higher (12\%) than the one found for the alteration over which it developed (8\%), it remains scarce. As for altered springbok, the red strip at Leopard Cave also falls inside the alteration pole. It presents higher differences in iron contribution between pigments (35\%) and substrate (27\%). Nonetheless, the Ca-S contribution is still predominant (above 50\%). Both the unburied traces and the pigment of the red giraffe present iron contribution that comprise between $40 \%$ and $80 \%$ and a $\mathrm{Ca}-\mathrm{S}$ contribution of $40 \%$ maximum. Both of these highly differentiate from their substrate thanks to their contributions of $\mathrm{Ca}-\mathrm{S}$ and $\mathrm{Fe}$.

Although most of the analyses of pigments distinguish them-selves from the substrate ones, their analyses only lead to the detection of iron oxide, bringing no other valuable pieces of information. Other elements were included in a qualitative comparison of elemental composition of the different figures, but the variations observed cannot be imputed to the sole pigments and could be ascribed to the contribution of elemental composition of the substrate and superficial alteration.

However, all rock paintings, with the exception of the springbok, presented a clear iron signal, characteristic from pictorial layers distinguishing themselves from the granite substrate, the iron-rich inclusions, and their alterations. For these reasons, these results allow defining a "pigment pole" in the ternary diagram of Fig. 7. Only one analysis of the red giraffe falls out of this "pigment pole"; it was performed on a spot presenting thinner deposits of pigments than the other analyses, explaining the higher contribution of the substrate and the clearly visible shift of this analysis toward the substrate pole.

Figure 8e locates the pXRF analyses performed on the red unburied traces and Fig. 8f presents two spectra collected from this area: one of the substrate and one of the traces of red pigment. The pigment presents higher iron content than the altered support. It confirms the presence of iron oxide, not imputable to the sediment, on the wall in previously buried levels. Minor and trace elements could not be exploited due to their high variability of content within the substrate. As sediments covered these red traces, they were protected from later alterations. As a result, they fall in a low altered area, whereas paintings present higher alterations. Such detection of iron pigment is of tremendous importance in providing chronological context to the rock paint-ings. Together with the study of the various tools and colored materials excavated at this site, it is likely that the presence of the red unburied traces will help to understand better the chronological context of the paintings found at the site. 

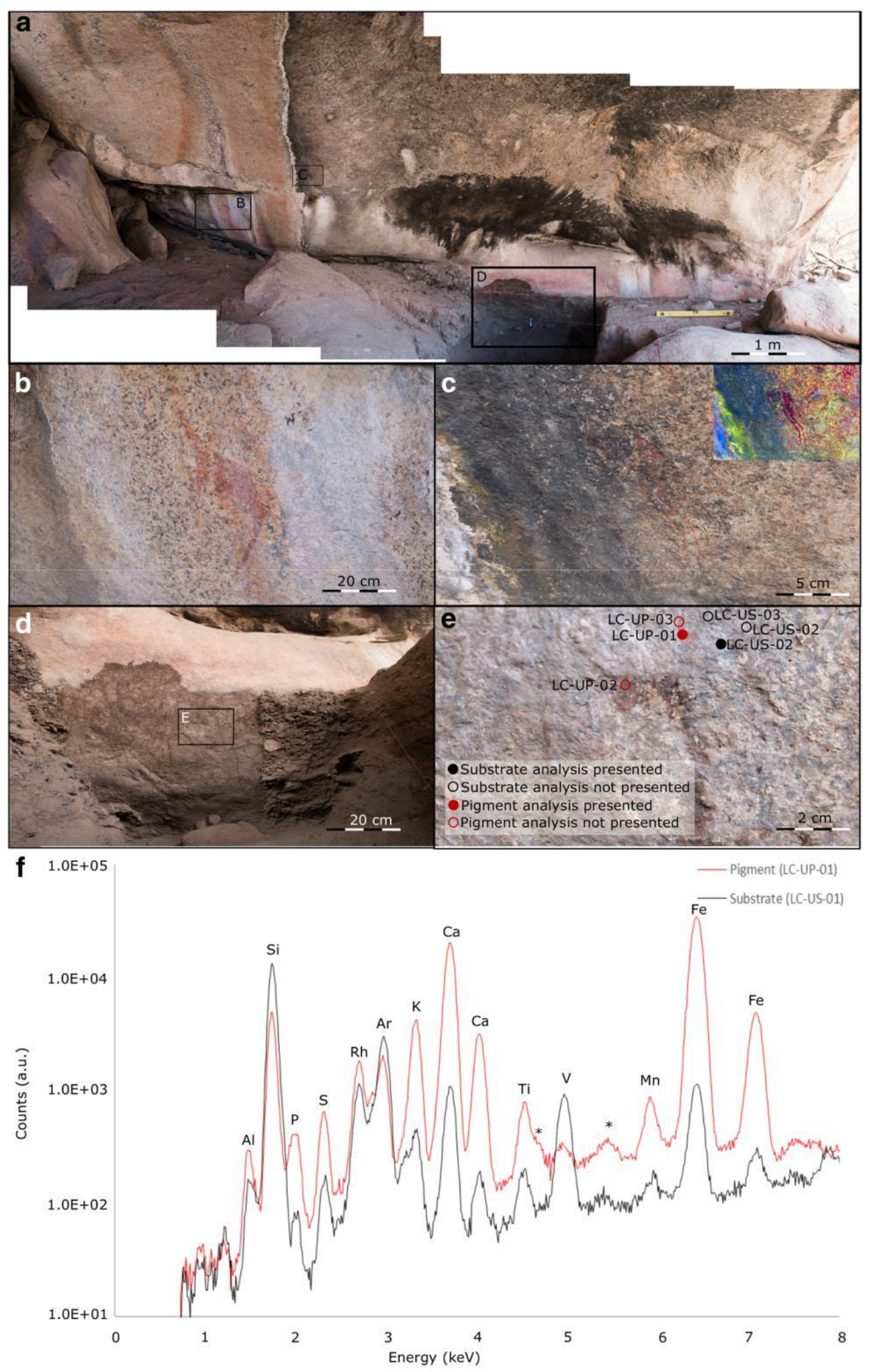

Fig. 8 In situ pXRF in an archeological context: analyses of Leopard Cave red paintings and traces: location of the various traces (a), the red giraffe painting (b), the altered springbok with D-stretched treatment in insert (c), the unburied red traces (d, e), and pXRF analyses (f) of the unburied red traces (red) and their support (black). Escape peaks are labeled with a *. Non-labeled peaks correspond to elements for which the presence could not be assessed due to the variability they exhibit on the different spectra acquired

Fackelträger is another important archeological site in Omandumba West farm, in the Erongo Mountains. Erich Wendt excavated it in the 1960s (Wendt 1972; Richter 1991). As Leopard Cave, the shelter hosts numerous rock paintings on the walls (Fig. 9a) at the bottom of which excavations revealed the presence of archeological colored materials and tools bearing traces of pigments. 
Therefore, Leopard Cave and Fackelträger are crucial sites to understand coloring agent use and rock art production in the region. Water leakage and different alterations weathered the numerous paintings of the site. Three paintings of sundry red hues but of good preservation state were analyzed: a thick purple unidentified figure made of pigment 1 (Fig. 9c), a thin headless pale red bovid made of pigment 2 (Fig. 9e), and a dark red giraffe made of pigment 3 (Fig. 9g).

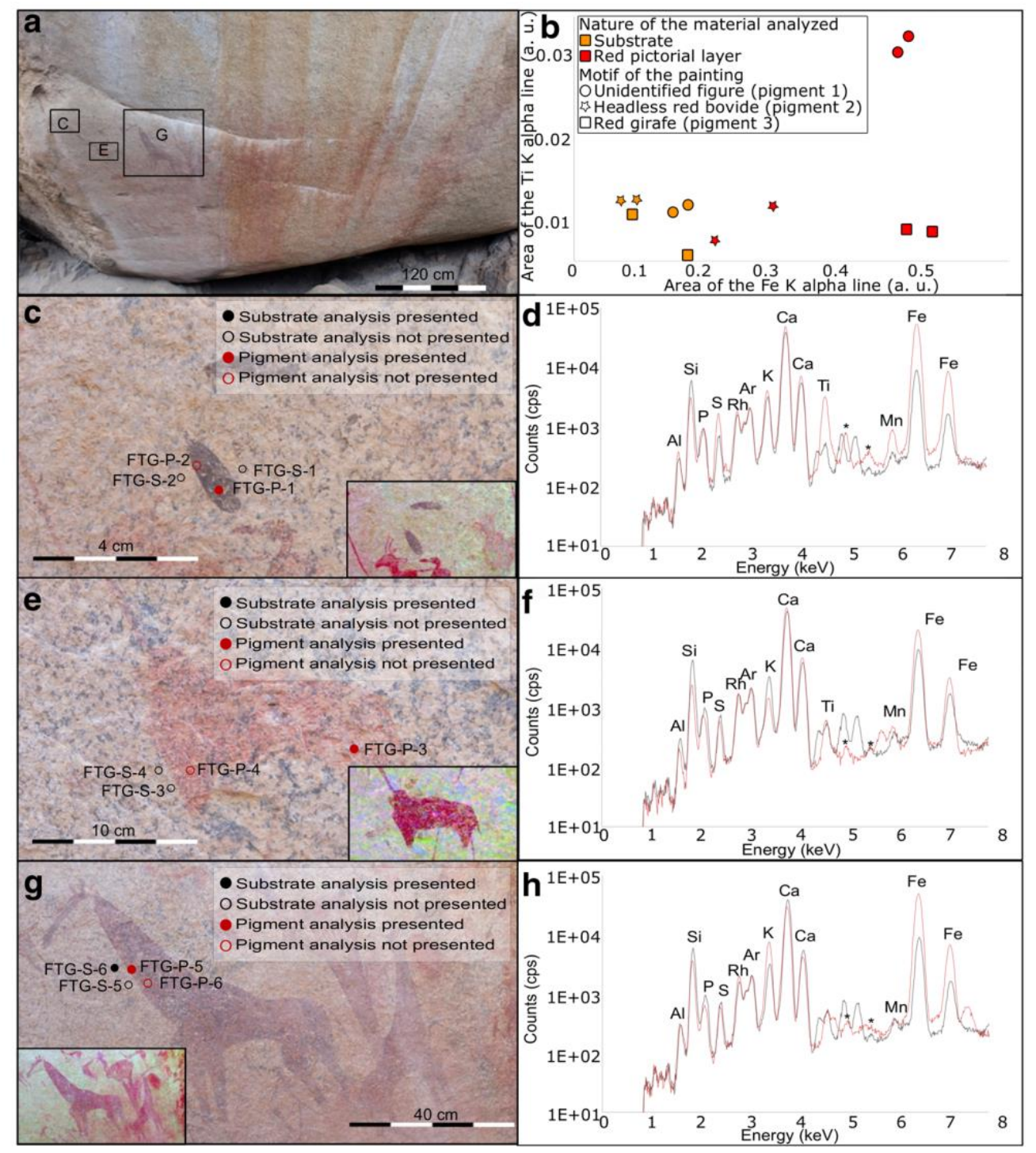

Fig. 9 Pigment analyses of the red pictorial layers of Fackelträger: location of the paintings (a) and distinction of the red pigments through their Ti and Fe contents (b): the purple unidentified figure (pigment 1, c and d), the red headless bovid (pigment 2, e and f), the dark red giraffe (pigment 3, $g$ and h). Escape peaks are labeled with a *. Non-labeled peaks correspond to elements for which the presence could not be assessed due to the variability they exhibit on the different spectra acquired

Figure $7 \mathrm{~b}$ shows that all the pigment analyses fall in the same "pigment pole" defined previously for Leopard Cave. Two trends appear, one with a low iron contribution corresponding to the thin pale pigment 2 and the other thicker two pigments. The point falling outside the pigment pole corresponds to the thinnest painting, where there is not enough material to proceed to trace analyses. The pigment pole here helps us identify the pigments for which there is enough material to investigate the diversity of the pigments and proceed to further analyses.

Figure $9 \mathrm{~b}$ presents the contribution of Ka iron peak area against the Ka titanium peak area for these three pigments and the substrate lying next to it. Both pigments 1 and 3 present larger area of the Ka iron peak, therefore higher amount of iron than their substrate. Pigment 1 exhibits higher titanium content than pigment 3. Pigment 2 does not separate well from the substrate when considering both of these elements. Therefore, the three pigments analyzed at Fackelträger illustrate three distinct situations.

To allow comparison of the pXRF spectra of the three distinct pigments, these pigments are presented together with the same spectrum of the substrate (FTG-S-6). Figure 9c lo-cates the analysis of the pigment 1 presented in Fig. 9d with the substrate 
analysis. Together with the high iron content, the pigments present clear Ti and Mn contents. Figure 9e locates the analyses performed on pigment 2. One of these spectra is presented in Fig. 9f together with the analysis of the substrate. Although there is a light higher iron content, no other elements could be imputed to the sole pictorial layer. Finally, Fig. 9g locates the analyses performed on pigment 3 and Fig. 9h presents the spectra of this pigment and of the substrate. Similarly to the analyses of pigment 2, no element other than iron could be imputed to the pictorial layer.

Although all red representations exhibited higher iron con-tent than their substrate, the elemental composition obtained by XRF could not be imputed to the sole nature of the pigment used. As visible with pigments 1 and 2 presented in Fig. 9, the thicknesses of the pigment layers vary greatly depending on the alteration state of the different parts of the panel. It leads to most of the discrepancies in the iron signal collected from the distinct paints. Moreover, as pXRF experiments bring information about both the pictorial layer and the substrate, the granite substrate presents iron variability that could also alter the signal collected from the rock painting analyses.

Spectra collected permitted to identify minor elements on few paintings, such as pigment 1 in Fig. 9c and Fig. 9d. This representation presents the highest content of $\mathrm{Fe}$ on Fackelträger panel. This painting corresponds to the thickest pictorial layer we encountered in the region, explaining the possibility to support the correlation between titanium and manganese with the pictorial layer. It distinguishes itself from the other paintings of Fackelträger due to its relatively high titanium content.

As illustrated in Fig. 9, pictorial layers of other red paintings, much thinner, present various iron content and the identification of associated minor elements is hard due to the variability of the substrate and the small thickness of the pictorial layer (Fig. 9e and Fig. 9f). However, with a closer examination of some minor elements, it is possible to go further and distinguish the different pigments. Hence, pigment 1 presents higher concentration of titanium than pigment 3, but similar Fe content, the substrate exhibiting low Ti content (Fig. 9b). For pigment 2, the estimation of the raw material composition is hard to distinguish from the contribution of the substrate since it presents similar level of Ti than the substrate and only light higher signal of Fe.

Only one other site presented similar thickness than in Fackelträger-Rain Cloud-where, despite the thickness of the pictorial layers, it was not possible to identify minor elements associated to the pictorial layers. The red paintings of Rain Cloud only presented various content of Fe, imputable to the amount or the nature of pigments analyzed. Differentiating these two possibilities would only be possible thanks to further investigations.

\section{General discussion}

As demonstrated for the red paintings of Leopard Cave, we generally could not distinguish the iron oxides between them. This is due to the complexity of rock painting systems, including various unknown layers preventing us from detecting characteristic elements associated to various iron oxides used to perform the red rock paintings. Therefore, their analyses face numerous issues due either to their nature or the equipment limits. Having this in mind is of tremendous importance not to over interpret the results.

\section{Technical and methodological limitations}

Together with the intrinsic heterogeneity of the granitic bed-rock and its alterations, the presence in the substrate of elements characteristic of pictorial layer such as Fe considerably complexifies the identification of the pigments thanks to the in situ pXRF analyses. As illustrated with the analyses of the various paintings investigated at Leopard Cave, our results pointed out the large influence of the variability of the substrate. As in the case of Ti in the spectra collected from the substrate and pigments of the red paintings analyzed at Fackelträger, this substrate variability limits us to bear any consideration about trace elements characteristic of the pictorial layer. In our study, the analyzed pigments are characterized by elements that are commonly found within alterations ( $\mathrm{Ca}$ and $\mathrm{S})$ such as it is the case for the white paintings at Ghost Cave, or even wholesome granite ( $\mathrm{Si}, \mathrm{Al}, \mathrm{K}$, and $\mathrm{Fe})$, as illustrated with the red paintings of Fackelträger. Indeed, for the red paintings, we analyzed iron oxide pigments lying over a granitic substrate containing unneglectable iron content, as the substrate of Fackelträger highlights it. It was subsequently hard to distinguish from the pXRF spectra the contribution imputable to the sole pictorial layer and one of the substrates, as shown with pigment 2 at Fackelträger. Such limits are intrinsic to the material analyzed and technological and methodological development might allow overpassing them.

However, the nature of the material analyzed led to some methodological restraints, demanding further treatments of the data collected on the field. A procedure to deal with multi-layered system is to subtract the spectra from the substrate to the ones of the upper layers, leaving the sole contribution of these last parts of the artifacts studied. The physical properties of the substrate, alterations, and paint layers prevented us from doing so. Indeed, as mentioned by Gay et al. (2015), the grain size of the various compounds also influences the pXRF analyses, leading to changes in their intensity. As on the field it is almost impossible to 
ensure the exact same geometric analyses conditions from one analysis to another, it is not possible to subtract a spectrum to another to identify the contribution of two distinct layers containing similar chemical elements

In Erongo case, higher limitations were encountered due to the substrate heterogeneity, which prevented in many cases to conduct any sourcing considerations. With a more homogeneous substrate such as limestone, limits due to the substrate are not as high (Chalmin and Huntley 2017; Gay et al. 2015). In those contexts, Gay et al. (2016) used the modelization of multi-layered system to quantify the elemental composition of the pictorial layers in order to distinguish later the pigments. In our case, the variability of the substrate composition makes such treatments impossible, as the composition of the pictorial layers is also unknown.

We thought that the ELIO pXRF equipment we used pro-vided data of higher interest than what we could have collected with most handheld portable XRF. As mentioned by Koenig et al. (2014), most pXRF rock art studies involve equipment producing a primary X-ray beam larger than the surface area of many paintings. Spot size usually turns around 0.5 to $1 \mathrm{~cm}$ in diameter. It leads to a major contribution of the substrate in the measured spectra, reducing the one of the pictorial layer. It is highly problematic in the case of heterogeneous substrate. To overcome the high heterogeneity of our substrate, the use of a small beam spot size (as the1.2-mm diameter of the ELIO pXRF equipment) is of tremendous importance. It allowed us to target a specific area, reducing the effect of the low amount of pictorial material still preserved on the paintings. Since the pictorial layers are not homogeneous, a bigger spot would lead to a higher contribution of the substrate to the detected fluorescence, further reducing the signal of the paint layer.

However, a small spot size raises the issue of the representativeness of the analyses, especially on a granitic heterogeneous support. At the studied sites, the thickness of the pictorial layers is thin. Exception made for the purple unidentified figure of Fackelträger, it is possible to observe the nature of the grain underlying all paintings. It provided us the opportunity to avoid the analysis of pictorial layers covering bedrock iron-rich inclusions, by considerably reducing the complexity of interferences between the substrate and the pictorial layer.

\section{Rock art taphonomy}

Our pXRF results highlighted the large presence of alterations over and above the paintings of the Erongo, as exemplified with the important contribution of rich $\mathrm{Ca}-\mathrm{S}$ minerals in most analyses. $\mathrm{Ca}-\mathrm{S}$ was here identified as an alterations indicator, as it can be seen with the analyses of the red giraffe and altered springbok at Leopard Cave. It also provided some data about the nature of alterations endangering rock art representations laying over a granitic substrate, which to our knowledge is poorly understood and investigated. It confirmed that these deposits, calcium sulfate at Ghost Cave and calcium carbonates or oxalates at Elephant Wall, Leopard Cave, and Rain Cloud, are similar to the ones found on limestone in similar arid and semi-arid areas such as in Australia (Chalmin and Huntley 2017; Chalmin et al. 2016; Roberts et al. 2015; Watchman 1990) and in South Africa (Bonneau et al. 2012, 2017).

The fact that incident pXRF experiment analyzes both the paint and the substrate complexifies the situation. Alterations and weathering not only decrease the amount of pigment but also led to the infiltration and deposit of accretions not physically separable from the pigment layers $\left(\mathrm{Bu}\right.$ et al. 2013). Calcite $\left(\mathrm{CaCO}_{3}\right)$, calcium oxalates $\left(\mathrm{CaC}_{2} \mathrm{O}_{4}\right)$, and calcium sulfates $(\mathrm{CaSO})_{4}$ are common alterations toggled with or covering rock art representations. These infiltrations harden the identification of the minor and trace elements characteristic of the pigment source. Indeed, they modify the composition of the paint layer and increase its secondary X-ray absorbance, reducing the detection limit of these elements of interest.

As this pioneer study allowed identifying various alterations, further studies will focus on their link with various biodeteriogens such as animal urea. As alteration crusts covering the paintings are thin, investigations are currently been carried out to test the possibility to date the alterations possibly containing oxalates such as those identified at Elephant Wall, Leopard Cave, and Rain Cloud. A lot has to be done to understand better the formation of these alteration deposits over the granite or pictorial layers. Future research will also assess the possibility to provide a chronological context to the rock art of the region. It is also envisioned that this study will be extended other rock painting sites in Erongo such as the Brandberg or Spitzkoppe in order to establish the diversities of pigments used in the production of rock paintings in Namibia.

\section{Nature of the pigments}

The identification of iron oxide in all the paintings analyzed supports the investigation of the provenience of the raw materials used to perform the paintings as carried out in other rock art contexts (Bedford et al. 2018; Huntley et al. 2013; Wallis et al. 2017). 
Although it was not possible to identify chemical element markers of the provenience pigments used to perform the paintings, our analyses lead to some considerations about the diversity and technical or cultural choices of the pigments used to perform the rock paintings.

First, our results clearly reject the use of manganese oxide to perform the black paintings. In European cave art, these were used at several sites to perform black paintings such as in Lascaux (Chalmin et al. 2006). Our results sustain the use of carbonaceous black, as evidenced at other sites of southern Africa (Bonneau 2016; Bonneau et al. 2012, 2017; Prinsloo et al. 2008; Tournié et al. 2011). Although in our study it was not possible to determine the exact nature of the carbonaceous black pigment used (geologic or organic), comparison with other sites of southern African sup-ports the use of organic charcoal (Bonneau 2016; Bonneau et al. 2012, 2017; Prinsloo et al. 2008; Tournié et al. 2011).

Despite the presence of several manganese ore formations $80 \mathrm{~km}$ east to the Erongo Mountains (Schreiber et al. 2010), no manganese-based black pigments could be detected in the studied paintings, possibly indicating a trend in the procurement strategy of past populations. This trend could be imputed to past populations' technical-cultural choices such as exemplified in studies about the use of ochre. Reasons for these preferences or considerations could involve technical properties such cohesion of the material, easiness to reduce in powder of these materials (Salomon et al. 2011), cultural beliefs (Rudner 1982; Salomon et al. 2012), or geographical constraints making the material easy or not to collect (Salomon et al. 2011, 2012).

In the case of the Erongo, the distance is short when compared to the potential sources mentioned by local people for the red pigments, who evoke sources located at around $150 \mathrm{~km}$ of Erongo Mountains. The absence of use of manganese oxides to perform black paintings within the six sites we have studied (Rain Cloud, Black Man Shelter, Elephant Wall, Ghost Cave, Cycle of Life Shelter, and Black Gnu Wall) could support a very specific technical choice or other considerations connected to cultural or geographical thinking. Indeed, it might be imputable to a limited range of materials employed to perform rock art. Among these materials, carbonaceous black such as charcoal could have been preferred to manganese oxides to perform the black paintings or manganese oxides could not even have been considered as a potential material to perform the paintings.

Concerning the white pigments, analyses performed on the paintings found at Cycle of Life Shelter allowed identifying calcium carbonate or oxalate. Both could be found near the site in the form of alteration for the white pigment used at Ghost Cave identified as calcium sulfate. Similarly, calcrete deposit in seasonal riverbeds, calcite of ostrich eggshell, or calcium carbonate and oxalate alterations of local rocks can be found at the vicinity of Elephant Wall. Therefore, possible sources of white pigments are found next to each site with paintings. Further considerations could only be emitted if it is possible to say if white paintings were only performed at these sites or if they were also performed at other sites but faded due to the sensibility of white pigments to weathering events.

As for the red pigments, we distinguished at Fackelträger the use of three distinct red pigments of possibly sundry origins thanks to their different contents in Fe, Mn, and Ti. The possibility to do so on this site opens up some opportunities of analyses for sites with thick pictorial layers. Furthermore, as distinct materials were identified, it tends to point out that the paintings were not all performed at the same time of realization, therefore supporting the existence of various realization phases with distinct material choice and strategies of usages. These realization phases could have corresponded either to distinct occupational phases or not.

Few rock art sites provide leaked pigments later covered with sediments, therefore providing some constraints of minimal age for the realization of paintings at the rock art site. In this way, the present work is of uttermost importance as it confirmed the existence of leaked red pigment later recovered by sediments at the site of Leopard Cave. Undergoing analyses are carried out to provide a minimal age to the leaked pigments of Leopard Cave and therefore contribute to the chronology of rock paintings of the Erongo Mountains.

We hope that future study of the archeological material discovered during the excavation of Fackelträger (Wendt 1972) and Leopard Cave (Pleurdeau et al. 2012) and painting microsamples will provide further insights about colored materials and pigment choices and procurement strategies of past population in Erongo Mountains.

\section{Conclusion}

The in situ pXRF analyses pioneered the analyses of pigments used in Namibian rock art and provided key information about the pigments used in the northwestern part of the Erongo and about the alteration covering some of the paintings. It led to the identification of two different kinds of black and white pigments, and of iron oxide for red paintings. It also brought key insights about the alterations covering the granitic bed-rock thanks to the identification of typical deposits of semi-arid and arid climatic conditions: calcium-rich mineral (sulfate, carbonate and/or oxalates).

Despite the limitations of in situ non-destructive analyses, preventing the impossibility to identify chemical element markers of the provenience of the materials, it also pointed out the existence of several distinct phases of realizations with the use of distinct materials for white and red paintings. The possible existence of several of realizations will be investigated in further 
research thanks to the analyses of the paintings and the archeological colored materials found in archeological layers of Leopard Cave.

Together with the detection of red pigment on a wall in archeological layers at the site of Leopard Cave, the identification of carbonaceous pigments and of possible calcium oxalate alterations trigs unique perspectives to provide a chronological context to the rock paintings of the Erongo.

This study demonstrates the possibility to identify the nature of the pigments on a heterogeneous granitic substrate thanks to pXRF experiments. It opens large perspectives in the study of Namibian rock analyses at a large scale, allowing a useful prescreening to investigate regional use of pigments to perform rock paintings.

\section{Acknowledgements}

The authors are very grateful to Ms. and Mr. Rust and their family for their kind permission to access and analyze the rock art sites located on their farm. The authors also thank the manager of the Ai-Aiba lodge for allowing the in situ analyses of Rain Cloud paintings.

The authors wish to express their sincere gratitude to the National Heritage Council of Namibia for allowing these analyses according to the permit 11/2015 renewed and extended with the renewal permit 04/ 2017 given to D.P.

The authors also thank the National Museum of Namibia and the French embassy in Namibia for their support to conduct the present study.

The French Ministry of Foreign Affairs supported this work through the funding of the MANAM project.

The authors also thank the LaBex BCDiv (Biological and Cultural Diversity) for the subsidy granted to the project "Dynamique des peuples en Namibie à l'Holocène-NAMIBIE (Windhoek, Erongo)" at the origin of the present investigation.

The authors also thank Sorbonnes Universités for financial support through the Chaire Polyre funding the PhD project of G.M., and the APaNam project funded by Observatoire des Patrimoines de Sorbonne Universités (OPUS).

\section{References}

Acevedo A, Franco N (2012) Aplicación de DStretch-ImageJ a imágenes digiteles del arte rupestre de Patagonia (Argentina). Comechingonia Virtual 6(2):152-175

Appoloni CR, Lopes F, Melquiades FL, Parellada CI (2009) In situ pigments study of rock art at Jaguariaíava 1 archeological site (Paraná, Brazil) by portable energy dispersive X-ray fluorescence (EDXRF). FUMDHAMentos 9:555-562

Aubert M, O'Connor S, McCulloch M, Mortimer G, Watchman A, Richer-LaFlèche M (2007) Uranium-series dating rock art in East Timor. J Archeol Sci 34:991-996

Beck L, Rousselièere H, Castaing J, Duran A, Lebon M, Lahlil S, Plassard F (2012) Analyze in situ des dessins préhistoriques de la grotte de Rouffignac par fluorescence X et diffraction X portable. ArcheoSciences 36:139-151

Beck L, Rousselière H, Castaing J, Duran A, Lebon M, Moignard B, Plassard F (2014) First use of portable system coupling X-ray diffraction and X-ray fluorescence for in-situ analysis of prehistoric rock art. Talanta 129:459-464

Bedford C, Robinson DW, Sturt F, Bernard J (2014) Making paintings in South Central California: a qualitative methodology for differentiating between in situ red rock art pigments using portable XRF. SCA Proceedings 28:286-296

Bedford C, Robinson DW, Gandy D (2018) Emidiano Blues: the California indigenous pigment palette and in situ analysis of an exotic color. Open Archeology 4:152-172

Bleek WH, Lloyd LC (1911) Specimens of Bushman folklore. George Allen \& Co, London

Blümel W, Emmermann R, Hüser K (1979) Geowissenschaftliche Beschreibung und Deutung eines südwestafrikanischen Vulkankomplexes. S.W.A Wissenscheftlichen Gesellschaft, Windhoek.

Bonneau A (2016) Geochemical characterization and direct dating of rock art using radiocarbon and optically stimulated luminescence: the case study of southern Africa and the Canadian shield. PhD dissertation, Université du Québec, Montréal.

Bonneau A, Pearce DG, Pollard AM (2012) A multi-technique characterization and provenance study of the pigments used in San rock art, South Africa. J Archeol Sci 2(39): 287-294.

Bonneau A, Pearce D, Mitchell P, Staff R, Arthur C, Mallen L, Brock F, Higham T (2017) The earliest directly dated rock paintings from south-ern Africa: new AMS radiocarbon dates. Antiquity 4(91):322-333

Breuil H (1955) The white lady of the Brandberg. Trianon Press, Paris Breuil H, Boyle ME, Scherz ER, Strey RG (1960) Anibib \& Omandumba, and other Erongo sites. Calouste Gulbenkian Foundation, Clairveaux.

Breuil H (1975) The Sphinx and White Ghost shelters and other Spitzkopje sites. Trianon Press, Paris

Bu K, Cizdziel JV, Russ J (2013) The source of iron-oxide pigments used in Pecos river style rock paints. Archaeometry 55: 1088-1100.

Chadefaux C, Vignaud C, Menu M, Reiche I (2008) Multianalytical study of Paleolithic reindeer antler. Discovery of antler traces in Lascaux pigments by TEM. Archaeometry 50(3): 516-534.

Chalmin E, Farges F, Vignaud C, Susini J, Menu M, Brown GE Jr (2006) Discovery of unusual mineral in Paleolithic black pigments from Lascaux (France) and Ekain (Spain). AIP Conference Proceedings, 882, 220-2. Contributed to 13th International Conference on X-ray Absorption Fine Structure (XAFS13), 9-14 July. Stanford, CA, p 2006

Chalmin E, Castets G, Delanoy J-J, David B, Barker B, Lamb L, Soufi F, Pairis S, Cersoy S, Martinetto P, Geneste J-M, Hoerlé S, Richards T, Gunn R (2016) Geochemical analysis of the painted panels at the 'Genyornis' rock art site, Arnhem Land, Australia. Quat Int 430:60-80

Chalmin E, Hoerlé S, Reiche I (2017) Taphonomy on the surface of the rock wall: rock-paint-atmosphere interactions. In: David B, McNiven IJ (eds) The Oxford Handbook of the Archeology and Anthropology of Rock Art. Oxford Handbook, http://www. oxfordhandbooks.com/view/10.1093/oxfordhb/9780190607357. 001.0001/oxfordhb-9780190607357-e-47. Accessed 22 June 2018 
Chalmin E, Huntley J (2017) Characterizing rock art pigments. In: David B, McNiven IJ (eds) The Oxford Handbook of the Archeology and Anthropology of Rock Art. Oxford University Press, from http:// w w w. o x fordh a n d b o ok s . c o m/vi e w/ $10.1093 /$ ox ford h b /9780190607357.001.0001/oxfordhb-9780190607357-e-48 . Accessed 22 June 2018

Charalambous A, Kassianidou V, Papasavvas G (2014) A compositional study of Cypriot bronzes dating to the Early Iron Age using portable X-ray fluorescence spectrometry (pXRF). J Archeol Sci 46:205-216

Clot A, Menu M, Walter P (1995) Manières de peindre des mains à Gargas et Tibiran, Hautes-Pyrénées. L'Anthropologie 99(2-3): 221-235.

Clottes J, Menu M, Walter P (1990) La préparation des peintures magdaléniennes des cavernes ariégeoises. Bulletin de la Société préhistorique française 87(6):170-192

Conard NJ, Breunig P, Gonska H, Marinetti G (1988) The feasibility of dating rock paintings from Brandberg, Namibia, with 14C. J Archeol Sci 15:463466

Dowson TA (1994) Reading art, writing history: rock art and social change in Southern Africa. World Archeology 25(3):332-345

Ferretti M, Plese C, Garcia CR (2013) X-Ray fluorescence investigation of gilded and enameled silver: the case study of four medieval processional crosses from central Italy. Spectrochim Acta B 83-84:21-27

Fontana D, Alberghina MF, Barraco R, Basile S, Tranchina L, Brai M, Gueli A, Troja SO (2014) Historical pigments characterization by quantitative Xray fluorescence. J Cult Herit 15:226-274

Frahm E, Doonan CP (2013) The technological versus methodological revolution of portable XRF in archeology. J Archeol Sci 40:1425-1434

Freundlich J, Schwabedissen H, Wendt W (1980) Köln Radiocarbon measurements II. Radiocarbon 22(1):68-81

García-Diez M, Hoffmann DL, Zilhão J, de las Heras C, Lasheras JA, Montes R, Pike AWG (2013) Uranium series dating reveals a long sequence of rock art at Altamira Cave (Santillana del Mar, Cantabria). J Archeol Sci 40:4098-4106

Gay M, Alfred M, Menu M, Laval E, Arias P, Ontañon R, Reiche I (2015) Paleolithic paint palettes used at La Garma Cave (Cantabria, Spain) investigated by means of combined in situ and synchrotron X-ray analytical methods. J Anal At Spectrom 30:767-776

Gay M, Müller K, Plassard F, Cleyet-Merle J-J, Arias P, Ontañon R, Reiche I (2016) Efficient quantification procedures for data evalua-tion of portable X-ray fluorescence - potential improvements for Paleolithic cave art knowledge. J Archeol Sci 12(10):878-886

Goren Y, Mommsen H, Klinger J (2011) Non-destructive provenance study of cuneiform tablets using portable X-ray fluorescence (pXRF). J Archeol Sci 38:684-696

Green H, Gleadow A, Finch D (2017a) Characterization of mineral de-position systems associated with rock art in the Kimberley region of northwest Australia. Data in Brief 14:813-835

Green H, Gleadow A, Finch D, Hergt J, Ouzman S (2017b) Mineral deposition systems at rock art sites, Kimberley, Northern Australia—field observations. J Archeol Sci 14:340-352

Harman J (2008): Digital enhancement of pictographs from Baja California. Trabajo presentado al Simposium Internacional de Arte Rupestre, Instituto Cubano de Antropología, Convento San Francisco de Asís, La Habana 2008.

Hincke M, Nys Y, Gautron J, Mann K, Rodriguez-Navarro AB, McKee MD (2012) The eggshell: structure, composition and mineralization. Front Biosci 1(17):1266-1280

Hoffman DL, Pike AWG, García-Diez M, Pettitt PB, Zilhão J (2016) Methods for U-series of CaCO3 crusts associated with Paleolithic cave art and application to Iberian sites. Quat Geochronol 36:104-119 Hoffmann DL, Utrilla P, Bea M, Pike AWG, García-Diez M, Zilhão J, Domingo R (2017) U-series dating of Paleolithic rock art at Fuente del Truncho (Aragón, Spain). Quat Int 432: 50-58.

Hoffmann DL, Standish CD, García-Diez M, Pettit PB, Milton JA, Zilhão J, Alcolea-González JJ, Cantalejo-Duarte P, Collado H, de Balbín R, Lorblanchet M, Ramos-Muñoz J, Weniger GCh, Pike AWG (2018) U-Th dating of carbonate crust reveals Neanderthal origin of Iberian cave art. Science 359(6378): 912-915.

Huntley J (2012) Taphonomy or paint recipe: in situ portable x-ray fluorescence analysis of two anthropomorphic motifs from the Woronora Plateau, New South Wales. Aust Archeology 75:78-94

Huntley J (2015) Looking up and looking down: pigment chemistry as a chronological marker in the Sydney Basin Rock Art Assemblage, Australia Rock Art Res 32:131-145

Huntley J, Galamban CF (2016) The material scientific investigation of rock art: contributions from non-invasive X-ray techniques. In: Bednarik RG, Fiore D, Basile M, Kumar G, Huisheng T (ed) Palaeoart and materiality: the scientific study of rock art, 1st edn. Archaeopress, Oxford, pp. 41-58.

Huntley J, Aubert M, Ross J, Brand HEA, Morwood MJ (2013) One color, (at least) two minerals: a study of Mulberry rock art pigment and a Mulberry pigment 'quarry' from the Kimberley, Northern Australia. Archaeometry 57:77-99

Huntley J, Westaway K, Gore D, Aubert M, Ross J, Morwood MJ (2016) Non-destructive or noninvasive? The potential effect of X-ray fluo-rescence spectrometers on luminescence age estimates of archeological samples. Geoarchaeology 31: 592-602.

Huntley J, George S, Sutton MJ, Taçon P (2018) Second-hand? Insights into the age and "authenticity" of colonial period rock art on the Sunshine Coast, Queensland, Australia. J Archeol Sci 17:163-172

Jacobson L, Pineda CA, Morris D, Peisach M, Pillay AE (1994) A preliminary report on the PIXE analysis of ostrich eggshell and its potential for provenience studies in southern Africa. In: Demirci S, Özer AM, Summers GD (ed) Archaeometry 94: proceedings of the 29th International Symposium on Archaeometry.Tubitak, Ankara, pp. 273-278.

Koenig CW, Castañeda AM, Boyd CE, Rowe MW, Steelman KL (2014) Portable X-ray fluorescence spectroscopy of pictographs: a case study from the lower Pecos canyonlands, Texas. Archaeometry 56:168-186

Lenssen-Erz T (1996) Perceptions du cadre écologique et ses expressions métaphoriques dans l'art rupestre du Brandberg (Namibie). L'Anthropologie 100(2/3):457-472

Lenssen-Erz T (1997) Metaphors of intactness of environment in Namibian rock paintings. In: Faulstich P (ed) Rock art as visual ecology. American Rock Art Research Association, Tucson AZ, pp. 43-54.

Lewis-Williams JD (1972) The syntax and function of the Giant's Castle rock paintings. South Afr Archeol Bull 27:49-65

Lewis-Williams JD (1974) Re-thinking the South African rock art. Origini 8:229-257

Lewis-Williams JD (1975) The Dakensberg rock paintings as an expres-sion of religious thought. In: Anati E, Les religions de la préhistoire. Centro Camuno di Studi Preistorici, Capo di Ponte.

Lewis-Williams JD (1980) Ethnography and iconography: aspects of southern San thought and art. Man 15:467-482

Lewis-Williams JD (1981) Believing and seeing: symbolic meanings in southern San rock art. Academic Press, London

Loendorf CR, Loendorf LL (2013) Analyzing red pictographs with por-table X-ray fluorescence. Am Indian Rock Art 39:143-150

López-Montalvo E, Villaverde V, Roldán C, Murcia S, Badal E (2014) An approximation to the study of black pigments in Cova Remigia (Castellón, Spain). Technical and cultural assessments of the use of carbon-based black pigments in Spanish Levantine Rock Art. J Archeol Sci 12(52):535-545

Maddhusudan Mehta J, McCall G, Marks T, Enloe J (2017) Geochemical source evaluation of archeological chert from the Carson mounds site in northwestern Mississippi using portable X-ray fluorescence (pXRF). J Archeol Sci 11:381-389

Mazel AD, Watchman AL (2003) Dating rock paintings in the Ukhahlamba-Drakensberg and the Biggarsberg, KwaZulu-Natal (South Africa). South Afr Humanit 15:59-73 
McDonald J, Steelman KL, Veth P, Mackey J, Loewen J, Thurber CR, Guilderson TP (2014) Results from the first intensive dating program for pigment art in the Australian arid zone: insights into recent social complexity. J Archeol Sci 46:195-204

Menu M, Walter P (1996) Les rythmes de l'art préhistorique. Techné 3:11-23

Nankela AM (2015) Rock art research in Namibia: a synopsis. Afr Stud 24(1):39-55

Nankela AM (2017) Rock art and landscape: an empirical analysis in the content, context and distribution of the rock art sites in Omandumba East and West, Erongo Region Namibia. PhD dissertation. In: Universidade de Tomar

Newman B, Loendorf L (2005) Portable X-ray fluorescence analysis of rock art pigments. Plains Anthropol 50(195):277-283

Nuevo MJ, Sánchez AM, Oliveira C, (de) Oliveira J (2012) In situ energy dispersive X-ray fluorescence analysis of rock art pigments from the 'Abrigo dos Gaivões' and 'Igreja dos Mouros' caves (Portugal). X-Ray Spectrom 41:1-5

Olivares M, Castro K, Corchón MS, Gárate D, Murelaga X, Sarmiento A, Etxebarria N (2013) Non-invasive portable instrumentation to study Paleolithic rock paintings: the case of La Peña Cave in San Roman de Candamo (Asturias, Spain). J Archeol Sci 40:1354-1360

Pager HL, Kuper R, Breunig P, Lenssen-Erz T (1989) The rock paintings of the Upper Brandberg. Pt. 1. Heinrich-Institut, Köln.

Pike AGW, Hoffmann DL, García-Diez M, Pettitt PB, Alcolea J, De Balbín R, González-Sainz C, de las Heras C, Lasheras JA, Montes R, Zilhão J (2012) U-series dating of Paleolithic art in 11 caves in Spain. Science 336:1409-1413

Plagnes V, Causse C, Fontugne M, Valladas H, Chazine J-M, Fage L-H (2003) Cross dating (Th/U-14C) of calcite covering prehistoric paintings in Borneo. Quat Res 60:172-179

Pleurdeau D, Imalwa E, Détroit F, Lesur J, Veldman A, Bahain J-J, Marais E (2012) Of sheep and men: earliest direct evidence of cap-rine domestication in Southern Africa at Leopard Cave (Erongo, Namibia). PLoS One 7(7):e40340

Prinsloo LC, Barnard W, Meiklejohn I, Hall K (2008) The first Raman spectroscopic study of San rock art in the Ukhahlamba Drakensberg Park, South Africa. J Raman Spectrosc 39:646-654

Prinsloo LC, Tournié A, Colomban P, Paris C, Bassett ST (2013) In search of the optimum Raman/IR signatures of potential ingredients used in San/Bushman rock art paint. J Archeol Sci 40:2981-2990

Richter J (1991) Fackelträger. In: Richter J (ed) Studien zur Urgeschichte Namibias. Heinrich Barth-Institut, Köln, pp. 39-55.

Richter J (1995) Prähistorische Felskunst und Besiedlung in Zentralnamibia. Archäologische Informationen 18(1): 19-30.

Richter J (2002) The giraffe people: Namibia's prehistoric artists. In: Tides of the Desert - Gezeiten der Wüste, contributions to the archeology and environmental history of Africa in honor of Rudolf Kuper. Africa Praehistorica, pp. 523-534.

Richter J, Vogelsang R (2008) Rock art in North-Western Central Namibia-its age and cultural background. In: Limprecht C, Biesele M (ed) Heritage and cultures in modern Namibia-in-depth views of the country. Klaus Hess Publishers, pp. 37-46.

Roberts A, Campbell I, Pring A, Bell G, Watchman A, Popelka-Filcoff RS, Lenehan CE, Gibson CT, Franklin N, Mannum Aboriginal Community Association Inc (2015) A multidisciplinary investiga-tion of a rock coating at Ngaut Ngaut (Devon Downs), South Australia. Aust Archeology 80:32-39

Roldán C, Murcia-Mascarós S, Ferrero J, Villaverde V, López E, Domingo I, Martínez R, Guillem PM (2010) Application of field portable EDXRF spectrometry to analysis of pigments of Levantine rock art. X-Ray Spectrom 5(39):243-250

Roldán C, Villaverde V, Ródenas I, Novelli F, Murcia S (2013) Preliminary analysis of Paleolithic black pigments in plaquettes from the Parpalló cave (Gandía, Spain) carried out by means of non-destructive techniques. J Archeol Sci 1(40):744-754

Rudner I (1982) Khoisan pigments and paints and their relationship to rock paintings. Annals of South African Museum 87. South African Museum, Cape Town.

Rudner I (1983) Paints of the Khoisan rock artists. Goodwin Series 4:14-20

Russ J, Palma LR, Loyd DH, Boutton TW, Coy MA (1996) Origin of the whewellite-rich rock crust in the Lower Pecos region of southwest Texas and its significance to paleoclimate reconstructions. Quat Res 46:27-36

Russ J, Kaluarachchi WD, Drummond L, Edwards HGM (1999) The nature of a whewellite-rich rock crust associated with pictographs in southwestern Texas. Stud Conserv 44:91-103

Salomon et al (2011) Stratégies spécialisées d'acquisition de pigments rouges durant le Châtelperronien de la grotte du Renne à Arcy-sur-Cure (Yonne, France). In: Paillet, P. (Ed.), Micro-analyses et datations de l'art préhistorique dans son contexte archéologique, PALEO, Paris, pp. 125-133.

Salomon H, Vignaud C, Coquinot Y, Beck L, Stringer C, STRIVAY D, D'Errico F (2012) Selection and heating of coloring materials in the Mousterian level of Es-Skhul (c. 100,000 years B.P., Mount Carmel, Israel). Archaeometry 54:698-722

Sanhidrián JL, Valladas H, Medina-Alcaide MA, Pons-Branchu E, Quiles A (2017) New perspectives for $14 \mathrm{C}$ dating of parietal markings using $\mathrm{CaCO}_{3}$ thin layers: an example in Nerja cave (Spain). J Archeol Sci 12:74-80

(de) Sanoit J, Cambellan D, Plassard F (2005) Caractérisation in situ du pigment noir de quelques œuvres pariétales de la Grotte de Rouffignac à l'aide d'un système portable d'analyze par fluorescence X (XRF). ArchéoSciences 29:61-68

Shao QF, Pons-Branchu E, Zhu QP, Wang W, Valladas H, Fontugne M (2017) High precision U/Th dating of the rock paintings at Mt. Huashan, Guangxi, southern China. Quat Res 88(1):1-13

Scherz ER (1970) Felsbilder in Südwest-Afrika. Böhlau Verlag.: Köln

Schreiber UM, Ajagbe SD, Holzförster F, Wanke A (2010) The Geology of Area 2114: Omaruru. Explanation of Sheet 2114 Scale 1:250000. Geological Survey of Namibia, Windhoek.

Sepúlveda M, Gutierrez S, Carcamo J, Oyadener A, Valenzuela D, Monti I, Santoro CM (2015) In situ X-ray fluorescence analysis of rock art paintings along the coast and valleys of the Atacama desert, northern Chile. Journal of the Chilean Chemical Society 60(1): 2822-2826.

Shackley MS (2011) An introduction to X-ray fluorescence spectrometry (XRF) analysis in archeology. In: Shackley MS (ed) X-ray fluorescence spectrometry (XRF) in geoarchaeology. Springer, New York, pp. 7-44.

Silva A, Mauran G, Rosado T, Mirão J, Candeias A, Carpetudo C, Caldeira AT (2017) A arte rupestre da gruta do escoural—novos dados analíticos sobre a pintura paleolítica. In: Arnaud JM, Matins(ed) Arqueologia em Portugal/2017—Estado da Questão. Greca—Artes Graficas, pp. 1003-1019. Solé VA, Papillon E, Cotte M, Walter P, Susini J (2007) A multiplatform code for the analysis of energy-dispersive X-ray fluorescence spec-tra. Spectrochim Acta B 62:63-68

Steyn R (2014) Portable X-ray fluorescence and nuclear microscopy techniques applied to the characterization of Southern African art paintings. Master dissertation, Stellenbosch University.

Tournié A, Prinsloo LC, Paris C, Colomban P, Smith B (2011) The first in situ Raman spectroscopic study of San rock art in South Africa: procedures and preliminary results. J Raman Spectrosc 3(42):399-406

Valladas H, Pons-Branchu E, Dumoulin JP, Quiles A, Sanchidrían JL, Medina-Alcaide MA (2017) U/Th and 14C crossdating of parietal calcite deposits: application to Nerja cave (Andalusia, Spain) and future perspectives. Radiocarbon 59(6):1955-1967

Velliky E, Reimer/Yumks R (2013) Rock paintings of Squamish val-ley, British Columbia: geochemical analysis of pigments using portable X-ray fluorescence spectrometry (pXRF). Am Indian Rock Art 39:131-141

Vinnicombe P (1972) Myth, motive, and selection in southern African rock art. Africa 42:192-204

Vinnicombe P (1976) People of the eland. Natal University Press, Pietermaritzburg. 
Wallis LA, Huntley J, Marsh M, Watchman A, Ewen A, Strano A (2017) PXRF analysis of a yellow ochre quarry and rock art motifs in the central Pilbara. J Anthropol Soc South Aust 40:134-155

Ward I, Watchman AL, Cole N, Morwood M (2001) Identification of minerals in pigments from aboriginal rock art in the Laura and Kimberley regions, Australia. Rock Art Res 18:15-23

Watchman A (1990) The weathering of Australian rock paintings. In: 50 ans après la découverte de Lascaux. Journée internationales d'étude sur la conservation de l'art rupestre. Dordogne (France) 20-23 aout 1990: 21-28.

Watchman A (1991) Age and composition of oxalate-rich crusts in the northern territory. Australia Studies in Conservation 36:24-32

Wendt WE (1972) Preliminary report on an archeological research programme in South West Africa. Cimbebasia 2: 1-61.

Wesley D, Jones T, Reepmeyer C (2014) Pigment geochemistry as chronological marker: the case of lead pigment in rock art in the Urrmarning 'Red Lily Lagoon' rock art precinct, western Arnhem Land. Australian Archeology 78(1): 1-9.

Willcox AR (1978) An analysis of the function of rock art. S Afr J Sci 74:59-64 